\title{
High-Resolution Topography and Geomorphology of Select Archeological Sites in Glen Canyon National Recreation Area, Arizona
}

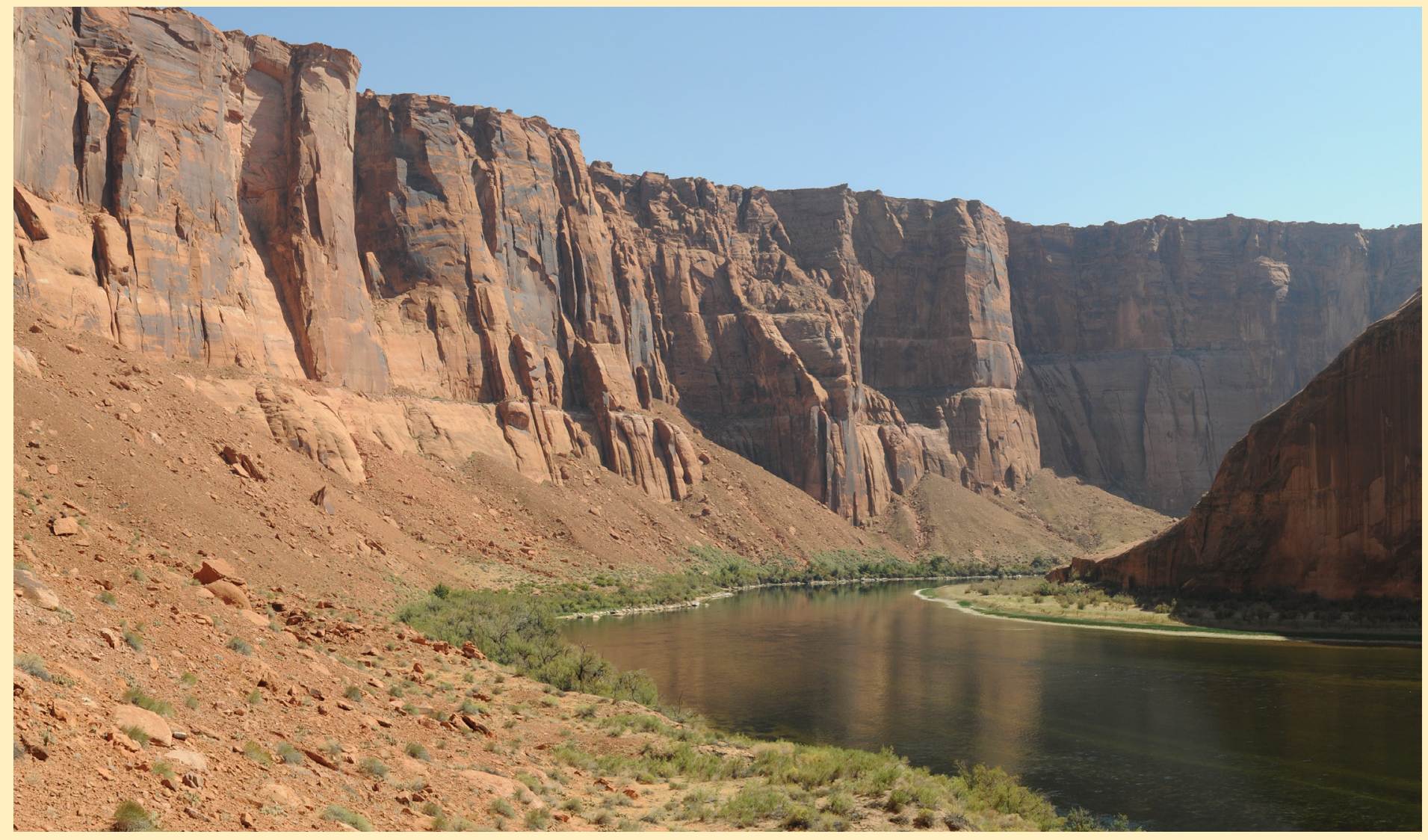

Scientific Investigations Report 2014-5126 
FRONT COVER

Talus slopes, and fluvial and alluvial terraces border the Colorado River through Glen Canyon National Recreation Area in Arizona. 


\section{High-Resolution Topography and Geomorphology of Select Archeological Sites in Glen Canyon National Recreation Area, Arizona}

By Brian D. Collins, Skye C. Corbett, Joel B. Sankey, and Helen C. Fairley

Scientific Investigations Report 2014-5126 


\section{U.S. Department of the Interior SALLY JEWELL, Secretary}

\section{U.S. Geological Survey Suzette M. Kimball, Acting Director}

U.S. Geological Survey, Reston, Virginia: 2014

For product and ordering information:

World Wide Web: http://www.usgs.gov/pubprod

Telephone: 1-888-ASK-USGS

For more information on the USGS—-the Federal source for science about the Earth, its natural and living resources, natural hazards, and the environment:

World Wide Web: http://www.usgs.gov

Telephone: 1-888-ASK-USGS

Any use of trade, firm, or product names is for descriptive purposes only and does not imply endorsement by the U.S. Government.

Although this report is in the public domain, permission must be secured from the individual copyright owners to reproduce any copyrighted material contained within this report.

Suggested citation:

Collins, B.D., Corbett, S.C., Sankey, J.B., and Fairley, H.C., 2014, High-Resolution Topography and Geomorphology of Select Archeological Sites in Glen Canyon National Recreation Area, Arizona: U.S. Geological Survey Scientific Investigations Report 2014-5126, 31 p., http://dx.doi.org/10.3133/sir20145126. 


\section{Contents}

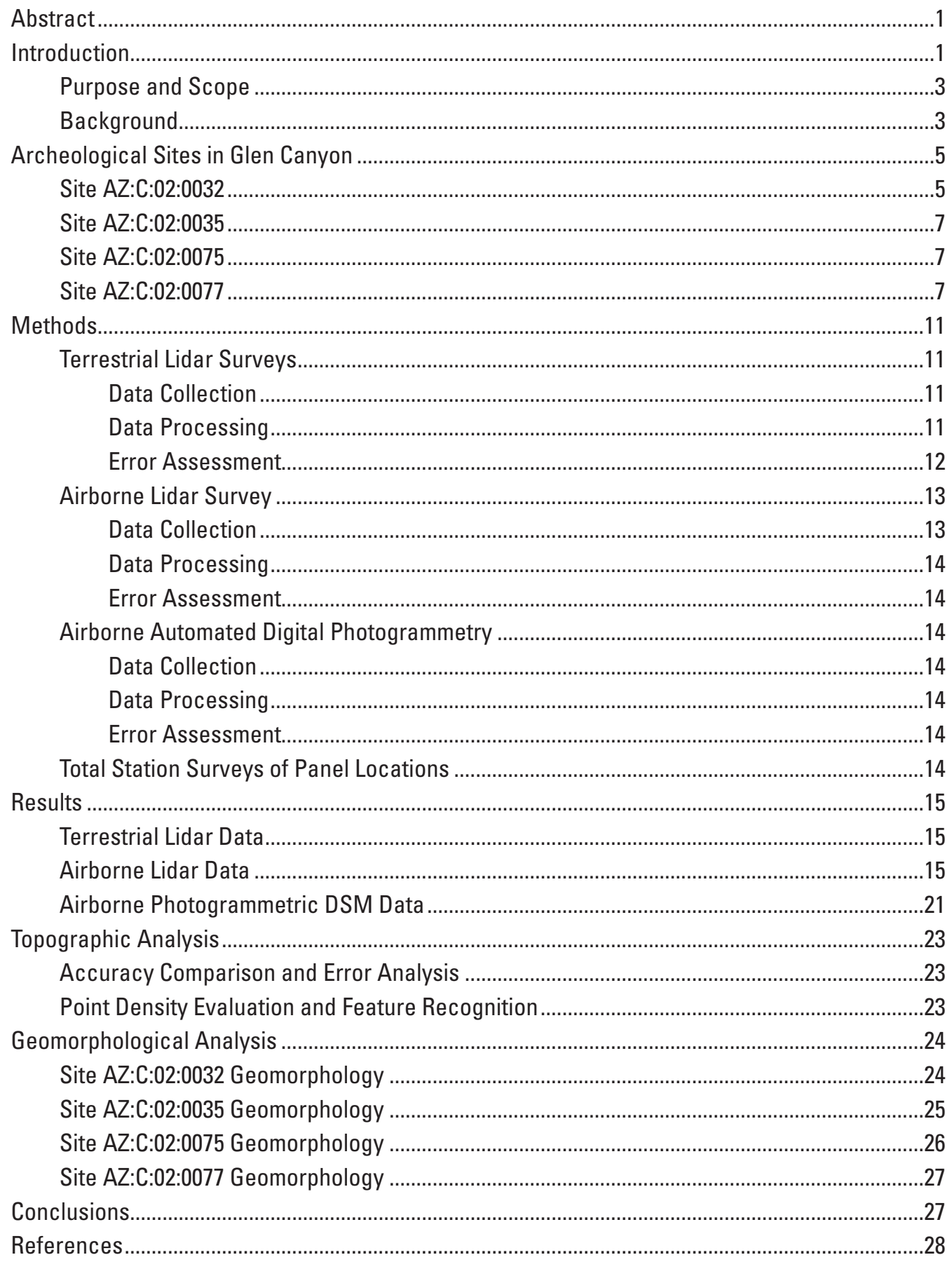




\section{Figures}

1. Regional map of Glen Canyon National Recreation Area showing area of airborne lidar data collection

2. Gullying at archeological site AZ:C:02:0032 and site AZ:C:02:0075 in Glen Canyon National Recreation Area

3. Site $A Z: C: 02: 0032$ survey map showing position of terrestrial lidar scanning locations, airborne lidar survey panels, and gully locations and flow paths.

4. Site AZ:C:02:0032 survey area photo showing gully locations...

5. Site $A Z: C: 02: 0035$ survey map showing position of terrestrial lidar scanning locations, airborne lidar survey panels, and gully locations and flow paths

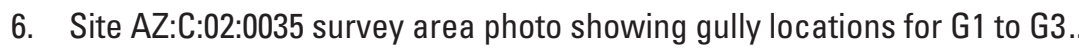

7. Site $A Z: C: 02: 0075$ survey map showing position of terrestrial lidar scanning locations, airborne lidar survey panels, and gully locations and flow paths .....................................

8. Site AZ:C:02:0075 survey area photo showing gully locations ..............................................

9. Site AZ:C:02:0077 survey map showing position of terrestrial lidar scanning locations, airborne lidar survey panels, and gully locations and flow paths ..................................10

10. Site AZ:C:02:0077 survey area photo showing gully locations.

11. Photo showing terrestrial lidar data collection in Glen Canyon National Recreation Area..11

12. Photo showing airborne lidar data collection in Glen Canyon National Recreation Area ....13

13. Photo showing iron-cross-type survey panel used for lidar data accuracy and point density comparison.

14. Site AZ:C:02:0032-Terrestrial lidar $5 \mathrm{~cm}$ gridded topographic surface map with $1 \mathrm{~m}$ contours and gully locations

15. Site AZ:C:02:0032 site boundary-Terrestrial lidar triangulated irregular network-based topographic surface map showing locations of gullies...

16. Site AZ:C:02:0035-Terrestrial lidar $5 \mathrm{~cm}$ gridded topographic surface map with $1 \mathrm{~m}$ contours and gully locations

17. Site $A Z: C: 02: 0035$ - Terrestrial lidar triangulated irregular network-based topographic surface map showing locations of gullies

18. Site AZ:C:02:0075-Terrestrial lidar $5 \mathrm{~cm}$ gridded topographic surface map with $1 \mathrm{~m}$ contours and gully locations

19. Site AZ:C:02:0075-Terrestrial lidar triangulated irregular network-based topographic surface map showing locations of gullies

20. Site AZ:C:02:0077-Terrestrial lidar $5 \mathrm{~cm}$ gridded topographic surface map with $1 \mathrm{~m}$ contours and gully locations

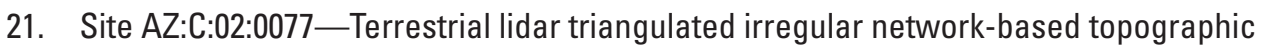
surface map showing locations of gullies...

22. Point-cloud data of vegetation and boulders at site AZ:C:02:0032

23. Surface resolution comparison at site AZ:C:02:0032, gully G3, among terrestrial lidar data, airborne lidar data and airborne photogrammetric digital surface model data

24. Results of objective gully delineation using airborne photogrammetric digital surface model data and topographic modeling at sites AZ:C:02:0032, AZ:C:02:0035 and AZ:C:02:0075 ..22 


\section{Tables}

1. Dates of data collection at archeological sites in the Colorado River corridor of

Glen Canyon National Recreational Area ..........................................................................5

2. Error assessment for maximum errors in terrestrial lidar data ..............................................12

3. Error assessment for maximum errors in airborne lidar point data .......................................14

4. Error assessment for maximum errors in airborne automated digital photogrammetry .......15

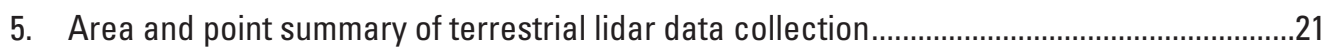

6. Area and point summary of airborne lidar data collection ...................................................21

7. Vertical accuracy comparison of survey panel center elevations using different methods.24

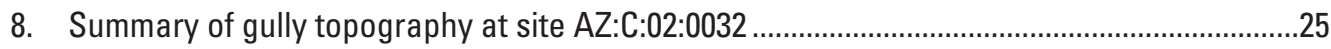

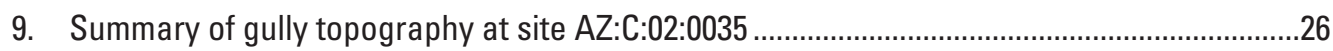

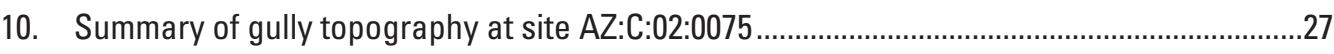

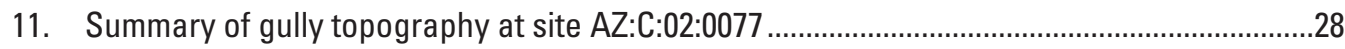

\section{Conversion Factors}

Inch/Pound to SI

\begin{tabular}{llll}
\hline \multicolumn{1}{c}{ Multiply } & \multicolumn{1}{c}{ By } & \multicolumn{1}{c}{ To obtain } \\
\hline & & Length & \\
\hline inch (in.) & 2.54 & & centimeter $(\mathrm{cm})$ \\
foot (ft) & 0.3048 & & meter $(\mathrm{m})$ \\
mile (mi) & 1.609 & & kilometer $(\mathrm{km})$ \\
\hline & & Flow rate & \\
\hline cubic foot per second $\left(\mathrm{ft}^{3} / \mathrm{s}\right)$ & 0.02832 & & cubic meter per second $\left(\mathrm{m}^{3} / \mathrm{s}\right)$ \\
\hline
\end{tabular}




\section{Acknowledgments}

Funding for this research was provided by the Bureau of Reclamation through the USGS Grand Canyon Monitoring and Research Center. David Bedford (USGS) assisted with terrestrial lidar data collection and Amy Draut (USGS) helped to field-check gully topography. Keith Kohl (USGS), Aaron Borling (USGS), Joeseph Hazel (Northern Arizona University), Robert Ross (USGS), and Daniel Hamill (USGS) provided field and office total station survey support. Rosemary Sucec (National Park Service) and Nathaniel Baker (National Park Service) accompanied us in the field and provided archeological interpretation. Carol Fritzinger (USGS), David Foster (USGS), and Seth Felder (USGS) provided logistical and river navigation support. We thank Stephen DeLong (USGS) and Sandra Bond (USGS) for providing detailed reviews that improved the quality of this report.

\section{Abbreviations}

$\begin{array}{ll}\text { ASCII } & \text { American Standard Code for Information Interchange } \\ \text { B.C.E. } & \text { Before Common Era } \\ \text { B.P. } & \text { Before Present } \\ \text { C.E. } & \text { Common Era } \\ \text { DEM } & \text { Digital Elevation Model } \\ \text { DSM } & \text { Digital Surface Model } \\ \text { GCMRC } & \text { Grand Canyon Monitoring and Research Center } \\ \text { GCNRA } & \text { Glen Canyon National Recreation Area } \\ \text { GIS } & \text { Geographic Information System } \\ \text { GPS } & \text { Global Positioning System } \\ \text { INU } & \text { Inertial Navigation Unit } \\ \text { NAD83 } & \text { North America Datum of 1983 } \\ \text { NA2011 } & \text { National Adjustment of 2011 (to the NAD83 datum) } \\ \text { RM } & \text { River Mile } \\ \text { RMS } & \text { Root Mean Square } \\ \text { TIN } & \text { Triangulated Irregular Network } \\ \text { USGS } & \text { United States Geological Survey }\end{array}$

\section{Datum Information}

Horizontal coordinate information is referenced to the North American Datum of 1983 National Adjustment of 2011 (NAD83) (NA2011) and projected to Arizona Central Zone 0202 State Plane coordinates, expressed in meters. For the purpose of protecting the sensitive nature of the archeological sites, all coordinates have been translated to a fictitious origin, still expressed in meters.

Vertical coordinate information is referenced to the North American Datum of 1983 - National Adjustment of 2011 (NAD83) (NA2011) ellipsoid height, expressed in meters.

Elevation, as used in this report, refers to distance above the vertical datum. 


\title{
High-Resolution Topography and Geomorphology of Select Archeological Sites in Glen Canyon National Recreation Area, Arizona
}

\author{
Brian D. Collins, Skye C. Corbett, Joel B. Sankey, and Helen C. Fairley
}

\section{Abstract}

Along the Colorado River corridor between Glen Canyon Dam and Lees Ferry, Arizona, located some $25 \mathrm{~km}$ downstream from the dam, archaeological sites dating from 8,000 years before present through the modern era are located within and on top of fluvial and alluvial terraces of the prehistorically undammed river. These terraces are known to have undergone significant erosion and retreat since emplacement of Glen Canyon Dam in 1963. Land managers and policy makers associated with managing the flow of the Colorado River are interested in understanding how the operations of Glen Canyon Dam have affected the archeological sites associated with these terraces and how dam-controlled flows currently interact with other landscape-shaping processes. In 2012, the U.S. Geological Survey initiated a research project in Glen Canyon to study the types and causes of erosion of the terraces. This report provides the first step towards this understanding by presenting comparative analyses on several types of high-resolution topographic data (airborne lidar, terrestrial lidar, and airborne photogrammetry) that can be used in the future to document and analyze changes to terrace-based archaeological sites.

Herein, we present topographic and geomorphologic data of four archaeological sites within a $14 \mathrm{~km}$ segment of Glen Canyon using each of the three data sources. In addition to comparing each method's suitability for adequately representing the topography of the sites, we also analyze the data within each site's context and describe the geomorphological processes responsible for erosion. Our results show that each method has its own strengths and weaknesses, and that terrestrial and airborne lidar are essentially interchangeable for many important topographic characterization and monitoring purposes. However, whereas terrestrial lidar provides enhanced capacity for feature recognition and gully morphology delineation, airborne methods (whether by way of laser or optical sensors) are better suited for reach- and regional-scale mapping. Our site-specific geomorphic analyses of the four archeological sites indicate that their current topographical conditions are a result of different and sometimes competing erosional agents, including bedrock- and terrace-based overland flow, fluvialinduced terrace bank collapse, and alluvial-fan-generated debris flows. Although the influences of anthropogenic-induced erosion from dam operations are not specifically analyzed in this report, we do identify geomorphic settings where dam operations are either more or less likely to affect archeological site stability. This information can be used to assist with future monitoring efforts of these sites and identification of similar conditions for other archeological sites along the Colorado River corridor in Glen Canyon.

\section{Introduction}

In arid and semi-arid regions around the world, it is a well-known paradox that running water and overland flow are responsible for erosion and significant reshaping of landscapes. In addition to wind and gravity agents, the pulses of water that carve these landscapes can be both powerful and intermittent, such that steep, spectacularly shaped topography results. Analyzing topographic data for these landscapes and changes in topography over time allows for an appreciation of how landforms originated, evolved, and may change in the future. However, quantifying the evolution of these landscapes can be challenging, particularly at the sub-regional (tens of square kilometers) and site scale $\left(<1 \mathrm{~km}^{2}\right)$, owing to the landscapes' highly irregular topography and the episodic nature of many erosion-causing events such as intense precipitation and flooding.

In northern Arizona, the Colorado River is the primary drainage and main agent responsible for carving the worldrenowned landscape features of Glen Canyon and the Grand Canyon. In 1963, with completion of Glen Canyon Dam $25 \mathrm{~km}$ upstream of the Grand Canyon, the Colorado River's natural hydrology was radically altered (Topping and others, 2003), with concomitant landscape effects and ecological consequences (U.S. Department of the Interior, 1995). These consequences include a reduction in the size and volume of sand bars (Schmidt and others, 2004; Hazel and others, 2010), an increase in riparian vegetation at low elevations and senescence of the riparian vegetation at higher elevations (Turner and Karpiscak, 1980; Waring, 1996), reduction in the amount of active aeolian sand dune areas (Draut, 2012), and lack of new sediment deposition by floods above the $1,274 \mathrm{~m}^{3} / \mathrm{s}(45,000$ cubic feet per second, $\mathrm{ft}^{3} / \mathrm{s}$ ) stage within the river corridor (Melis, 2011). In combination, these changes appear to have resulted in an increase in gully erosion and gradual exposure of buried 
archeological sites situated in and on the pre-dam alluvial terraces above the level of the active river channel (Fairley, 2005; Fairley and Sondossi, 2010).

In the corridor immediately below Glen Canyon Dam (fig. 1) and extending $25 \mathrm{~km}$ downstream to the historical river crossing at Lees Ferry, the Colorado River winds its way through a spectacular, sheer-walled canyon. At intermittent locations within this canyon, the river is bounded by eroded remnants of high-elevation (relative to current river flow level) fluvial and alluvial terraces (see cover), some of which were originally deposited more than 8,000 years ago (Anderson, 2006). Within and on top of these terraces are numerous archeological sites dating between 8,000 years before present through the modern era (Geib, 1990; Fairley and others, 1994; Spurr and Collette, 2007). These terraces are known to have undergone significant erosion and retreat since emplacement of Glen Canyon Dam (fig. 2; Grams and others, 2007). Land managers and policy makers associated with managing the flow of the Colorado River are interested in understanding how the operations of Glen Canyon Dam have affected these deposits and how dam-controlled flows currently interact with other landscape-shaping processes such as precipitationinduced erosion, riparian vegetation expansion, and human recreational activities to alter the riparian landscape in lower Glen and Grand Canyons. One topic of particular interest to land managers of the Glen Canyon National Recreation Area (GCNRA) concerns how dam operations may be affecting the fine-grained Holocene fluvial deposits in lower Glen Canyon that serve as the foundation and primary geomorphic context for the many prehistoric archeological sites found in this reach (Fairley and others, 1994) and that also provide settings for modern recreational campsites.

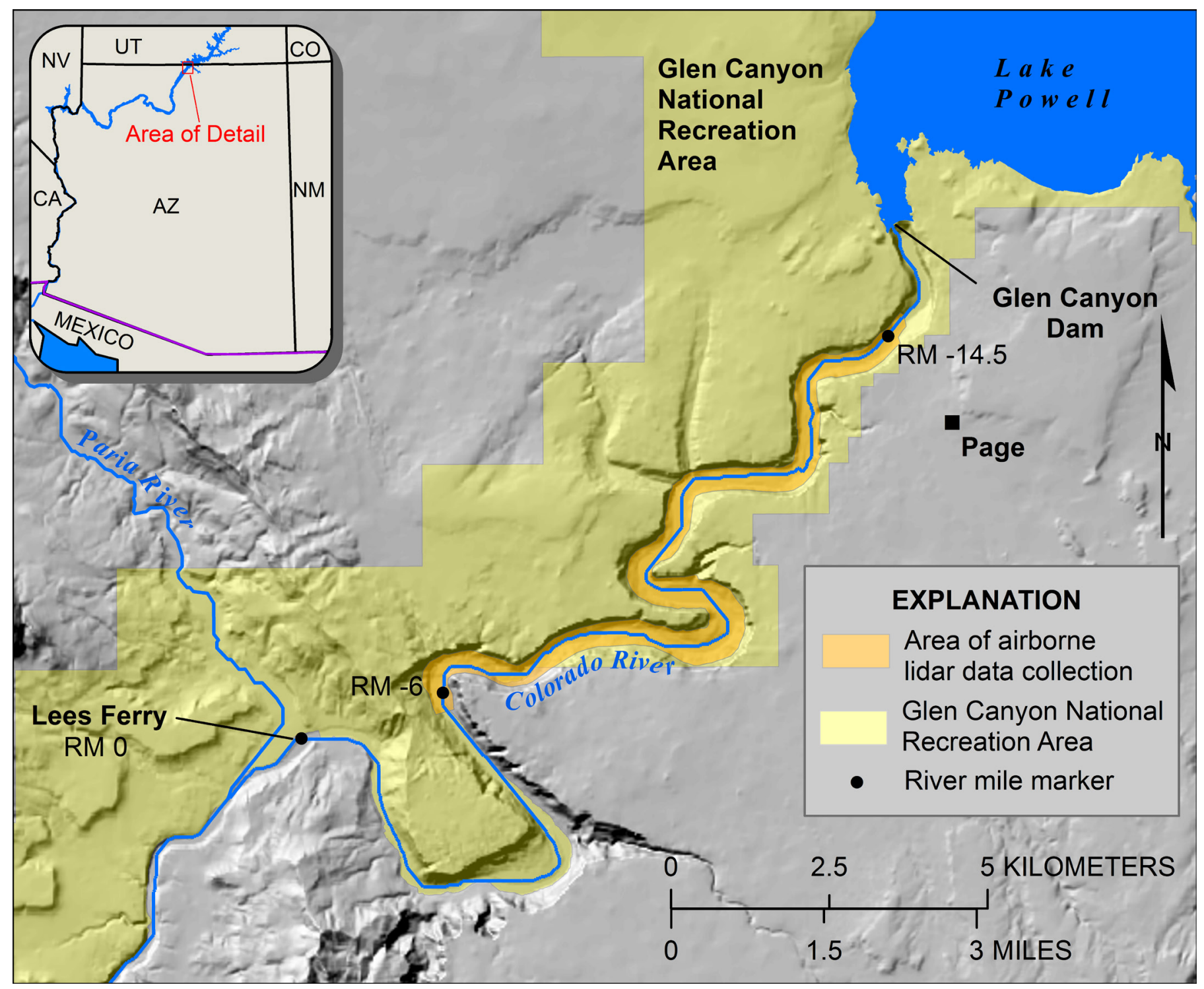

Figure 1. Regional map of Glen Canyon National Recreation Area (yellow) showing area of airborne lidar data collection (orange). River miles (RM) are measured using negative numbers upstream from Lee's Ferry (RM 0). The locations of the four archeological sites investigated in this report are not shown to protect the archeological resources from visitation-induced disturbance. 

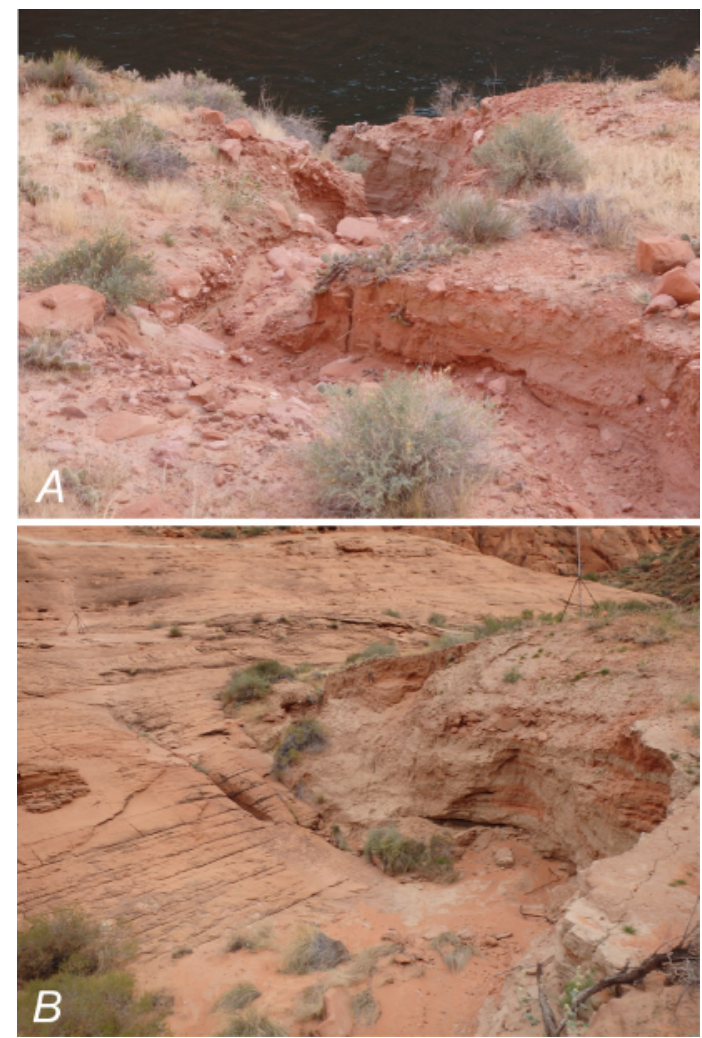

Figure 2. Gullying at $(A)$ archeological site $A Z: C: 02: 0032$ and $(B)$ site AZ:C:02:0075 in Glen Canyon National Recreation Area. These areas contain cultural artifacts buried by sediments subject to precipitation-induced erosion. Gully in $(A)$ is $\sim 1.6 \mathrm{~m}$ wide and runs over terrace edge to the Colorado River (in background). Gully in $(B)$ is $2.5 \mathrm{~m}$ deep and is partly controlled by overland flow from bedrock surfaces (shown in left of photo). Survey rod in upper right of $(B)$ is $\sim 2.5 \mathrm{~m}$ tall.

\section{Purpose and Scope}

In 2012, the U.S. Geological Survey (USGS) initiated a research project in lower Glen Canyon to study the types and specific causes of the ongoing erosion of the Holocene terraces, to assess the rate at which erosion is occurring, and to better elucidate the role of dam operations in contributing to the erosion of these sedimentary deposits. A primary goal of this research project is to identify the current geomorphic state of the selected archeological sites and establish whether these geomorphic states are what would be expected given historical weather patterns and dam operations. A secondary goal is to address whether the state of erosion in Glen Canyon is higher than in river segments downstream of Lees Ferry in Marble and Grand Canyons, where the availability of fine-grained sediment from major tributaries (for example, the Paria River, the Little Colorado River, Havasu Creek, and other large tributaries) has the potential to influence site stability.

To work towards these goals, we investigated four focused study areas within a $14 \mathrm{~km}$ segment of the Glen Canyon reach immediately downstream of Glen Canyon Dam, where archeological resources had been previously identified. Because detailed maps of the study areas were not available, the first step in this research required developing highresolution topographic representations of both the study area archeological sites and the entire targeted reach. Currently available options for creating high-quality terrain models vary greatly in terms of the resolution achievable and in the cost (including time and money). Therefore, in addition to developing and analyzing topographic models representing the Glen Canyon Holocene terraces and associated archeological sites, this study evaluated several currently available methods for representing the Holocene topography of Glen Canyon. These methods include terrestrial (ground-based) lidar, airborne lidar, and airborne, automated photogrammetry. Consequently, this report presents two different types of research results: (1) an evaluation of the quality and resolution of the three methods for representing the topography of Holocene deposits in the Glen Canyon reach, along with a comparison of their suitability for informing different aspects of the current geomorphology research project; and (2) an analysis of the topographic data derived from the above methods that focuses on identifying and describing the geomorphological processes responsible for erosion of Holocene deposits at four archeological sites within a $14 \mathrm{~km}$ reach of Glen Canyon downstream of the dam.

This report begins with a background overview of two hypotheses governing current thinking on the relationship between archeological site erosion and the operations of Glen Canyon Dam. We show how the data collected herein can be used to investigate the validity of these hypotheses. We then present thorough descriptions of the four archeological sites which were selected for our data collection efforts. A section on methods follows and describes procedures used for data collection, data processing, and error assessment of each remote sensing technique (terrestrial lidar, airborne lidar, and airborne automated digital photogrammetry) as well as the use of total station surveying for georeferencing the data sets. The data sets are compared to one another using both quantitative (point density) and qualitative (feature recognition) metrics. Finally, all of the combined data sets are used to identify the current geomorphological state of each of the four selected archeological sites. The report concludes with a discussion on the use of the data sets for answering additional geomorphological questions related to the role of dam operations on archeological site erosion.

\section{Background}

Prior to the completion of Glen Canyon Dam in 1963, the area upstream of the dam formed a vast eroded landscape that served as a source of the large quantities of sediment that were transported by the Colorado River. Some of this sediment was deposited downstream in the lower reaches of Glen Canyon and throughout Grand Canyon. With dam construction came regulated, power-generating water releases and the accumulation of sediment upstream of the dam. This altered both 
High-Resolution Topography and Geomorphology of Select Archeological Sites in Glen Canyon National Recreation Area

the natural hydrology and sediment supply conditions in the downstream canyons, including lowering of the riverbed elevation and coarsening of bed texture. It also exacerbated sediment evacuation from pools and the incision of knickpoints at riffles (Grams and others, 2007). The risers of terraces that form cutbanks to the main stem Colorado River have also eroded in response to the post-dam flow regime. Grams and others (2007) determined that this type of terrace-bank erosion was greatest immediately after completion of the dam and stabilized in recent decades. In addition, Hereford and others (1993) argued that gully-induced erosion of the Holocene-age sediment on the terrace treads and talus-covered slopes that form the substrate of many cultural sites adjacent to the river had increased during the past few decades prior to their study. Several factors have been proposed to explain the apparent increase in erosion rates, including (1) the absence of periodic sediment-rich flood flows in the post-dam era leading to a reduction in sand bars and the overall sediment supply, (2) increased intensity and magnitude of rainfall during the late 1970s and early 1980s, (3) a decrease in aeolian sand cover, and (4) secondary effects related to increased visitation and cumulative impacts from recreational use of the river corridor (Hereford and others, 1993; Thompson and Potochnik, 2000; Fairley, 2005).

During the past 25 years, two related hypotheses have been proposed to explain how dam operations affect the cultural sites located downstream of the dam. One hypothesis (Hereford and others, 1993) suggests that the system-wide decrease in fine sediment and the absence of sediment-rich spring floods, especially at elevations typical of the pre-dam floods (Topping and others, 2003), has removed an important process that formerly offset the effect of hillslope erosion, causing gullies to progressively incise and prograde upslope throughout their drainage networks. Hereford and others (1993) argued that the mouths of ephemeral tributaries in the pre-dam era were typically graded to the elevation of alluvial terrace surfaces high above the elevation of typical base flows. Although tributaries would progressively erode down to lower elevations typical of base flows, frequent high magnitude floods with relatively high suspended-sediment concentrations periodically backfilled the gully mouths (McKee, 1938) and reset the effective base level and grade of the tributaries. In the modern, sediment-depleted conditions of the Glen Canyon Dam era, gully mouths have not regularly refilled with flood alluvium, and gullies have consequently continued to downcut and increase in size, depth, and length, allowing erosion to propagate throughout the tributary watersheds (Hereford and others, 1993). Although the hypothesized connection of gully evolution to changes in effective base level is in keeping with some gully evolution models (for example, Schumm and others, 1984), the application of this hypothesis to management of archeological sites in the river corridor has been controversial (for example, Doelle, 2000). Nonetheless, the conceptual model proposed by Hereford and others (1993) still influences current geomorphological thinking on the issue.

A second, more recent, hypothesis focuses on the role of wind-blown sand in affecting surface infiltration capacity and gully backfilling processes (Thompson and Potochnik, 2000; Draut and Rubin, 2008). This hypothesis posits that the reduction in the number and areal extent of high-elevation sand bars (Schmidt and others, 2004; Hazel and others, 2010; Schmidt and Grams, 2011a) has resulted in a reduction in the amount of sand available to be transported inland towards archeological sites by wind; this, in turn, has changed the depth and surface characteristics of aeolian sand cover at many archeological sites (Lucchitta, 1991; Thompson and Potochnik, 2000; Draut and Rubin, 2008; Draut, 2012). The post-dam decrease in large, unvegetated sandbars is therefore hypothesized to have resulted in a consequent increase in the amount and intensity of surface erosion at archeological sites due to a decrease in sand transport to the sites. Aeolian sand transport is able to counteract surface erosion to some degree by (1) creating expanses of surficial sand with high infiltration capacity that can absorb rainfall and (2) filling in small gullies that form during rainfall-induced overland flow events. Draut (2012) posits that today's aeolian processes are only effective at controlling gully erosion where there are large sand bars with surficial sediments available to be entrained by wind, and where the bars are appropriately positioned relative to the prevailing winds so that the sediment is transported toward downwind terraces and archaeological sites. However, in the pre-dam era, expanses of unvegetated sand were more common due to the frequency of high-magnitude sediment-enriched spring floods (Topping and others, 2003), and the effects of aeolian sand redistribution on slowing erosion might have been more widespread.

To explore the validity of these hypotheses and to develop appropriate mitigation strategies, system-wide and site-specific geomorphologic characterizations of the modern landscape are needed, along with data on rates and amounts of erosion. The data presented herein can be used to perform these types of analyses. For example, high-resolution, sitespecific topographic data (that is, from terrestrial lidar) can be used to assess the present geomorphological state and identify current erosional and depositional processes (for example, overland flow, terrace bank collapse, aeolian transport). Further, site-specific archeological site monitoring based on repeat measurements of surface topography can be used to determine background rates of erosion. Such monitoring has already been implemented in Grand Canyon at select sites during the past decade, increasing in both detail and accuracy with subsequent monitoring efforts (Pederson and others, 2003, 2006; Hazel and others, 2008; Collins and Kayen, 2006; Collins and others, 2008; 2009; 2012). More extensive regional data (that is, from airborne lidar or airborne photogrammetry) can be used to quantify the overall state of erosion in Glen Canyon and compared to areas in downstream reaches of Grand Canyon where sediment inputs from tributaries are more substantial. If the state of erosion is determined to be higher in Glen Canyon (an area without significant sediment input), this would be an indication that erosion in river reaches with greater sediment input from tributaries (that is, Marble and Grand Canyons) have the potential to be mitigated by dam 
operations that promote sediment storage in sand bars and redistribution by wind (for example, high-flow experiments timed with the spring windy season-see Draut and Rubin, 2008). Thus, these data have the potential to address outstanding questions with regard to the role of dam operations on archeological site stability.

\section{Archeological Sites in Glen Canyon}

The American Southwest is world-famous for its abundance of well-preserved archeological sites, including those found in the Glen Canyon region of southern Utah and northern Arizona (Geib, 1996; Jennings, 1998; Crampton, 2009). Prior to the construction of Glen Canyon Dam, Federal managers recognized that impoundment of Lake Powell behind the dam would submerge many significant prehistoric and historical sites in this region. Therefore, prior to and during the dam's construction, the National Park Service compiled extensive inventories of archeological sites in Glen Canyon and its tributaries upstream of the dam. Approximately 2,000 archaeological sites were documented and over 200 were excavated (Geib, 1996; Jennings, 1998), however, very little attention was paid to the cultural resources in the river corridor downstream from the dam. Consequently, it was not until the early 1980s that systematic inventories of archeological sites located downstream of the dam in Glen Canyon were initiated (Geib, 1990).

The first efforts at documenting the archeological resources in lower Glen Canyon (that is, below the dam) focused on recording sites that had been previously found by recreationists and National Park Service personnel (Geib, 1990). In 1991, a comprehensive inventory of the entire Glen Canyon reach from the base of Glen Canyon Dam to Lees Ferry was completed (Fairley and others, 1994). This inventory documented a total of 45 archeological sites in the Glen Canyon reach, including rock art panels, artifact scatters and fire pits representing short-term seasonal camps, natural rock shelters with masonry structures, historic Navajo structures (sweat lodges, houses, corrals), mining sites, historic roads and inscriptions, a sunken steamboat, and several remnants of the old ferry crossings and USGS gaging sites near Lees Ferry. Many of the sites are situated on sheer cliff faces or on bedrock benches well above the historic high-water line of the pre-dam Colorado River, and thus they are not susceptible to direct erosion linked to dam operations. However, a number of the sites are situated on or in the Holocene-age alluvial terraces bordering the Colorado River, and are either eroding or have the potential to erode in the near future. These latter sites are the focus of the research efforts in Glen Canyon presented in this report.

We selected four sites with a variety of erosional features for our monitoring efforts; of the sites, three (AZ C:02:0032, AZ C:02:75 and AZ C:02:77) have been the focus of past subsurface investigations (Leap and Neal, 1992; Neff and Wilson,
2002; Wilson and Neff, 2002; Anderson, 2006; Pederson and others, 2011). These sites are situated only a few kilometers downstream from Glen Canyon Dam, where sediment inputs to the system are minimal, ongoing erosion of cultural deposits is evident, and bed lowering and sediment evacuation of the main stem Colorado River has been greatest since the construction of the dam (Grams and others, 2007). Thus, the selected sites are located in areas where both hypotheses regarding dam operation effects on downstream cultural sites would suggest that erosion rates are greatest for the river corridor, thereby providing an upper bound for erosional expectations at other sites downriver in Marble and Grand Canyons. To protect the sensitive nature of the archeological sites, specific site location information is omitted from this report, and the GCNRA archeological site identification number is used for reference (table 1).

Table 1. Dates of data collection at archeological sites in the Colorado River corridor of Glen Canyon National Recreational Area.

\begin{tabular}{cccc}
\hline $\begin{array}{c}\text { Archeological } \\
\text { site }\end{array}$ & $\begin{array}{c}\text { Terrestrial } \\
\text { lidar }\end{array}$ & Airborne lidar & $\begin{array}{c}\text { Airborne } \\
\text { digital photo- } \\
\text { grammetry }\end{array}$ \\
\hline AZ:C:02:0032 & $9 / 18 / 2012$ & $7 / 10 / 2013$ & $5 / 25 / 2009$ \\
AZ:C:02:0035 & $9 / 19 / 2012$ & $7 / 10 / 2013$ & $5 / 25 / 2009$ \\
AZ:C:02:0075 & $9 / 20 / 2012$ & $7 / 10 / 2013$ & $5 / 25 / 2009$ \\
AZ:C:02:0077 & $9 / 21 / 2012$ & $7 / 10 / 2013$ & $5 / 25 / 2009$ \\
\hline
\end{tabular}

\section{Site AZ:C:02:0032}

Site AZ:C:02:0032 lies on a terrace tread adjacent to a 11-m-tall cutbank bordering the Colorado River (figs. 3 and 4). Geoarcheological analyses in the area indicate that the deposits represent at least three different cut-and-fill episodes, with alluvium of protohistoric age (post- 1400 C.E.) and Puebloan age (900-1200 C.E.) overtopping and infilling gullies cut into a much older alluvial deposit composed of inter-bedded fluvial and slope-wash deposits (Anderson, 2006; Pederson and others, 2011). The vegetation in and around the site is a xeric shrub community consisting of irregularly spaced grasses, Fourwing saltbush (Atriplex canescens) and Mormon tea (Ephedra sp.) bushes, and prickly pear cacti (Opuntia polyacantha var. erinacea).

Archeological evidence consists of charcoal-stained deposits, and lenses of charcoal chunks and burned sediment exposed $30 \mathrm{~cm}$ to more than $2 \mathrm{~m}$ below the present ground surface (Leap and Neal, 1992; Pederson and others, 2011). Because the charcoal-stained deposits are only exposed in the cutbank, and previous excavations were not designed to determine the full extent of subsurface cultural deposits, the areal extent of this site remains unknown. Consequently, the site boundaries shown in figure 3 are estimates of the extent of archeological resources delineated during our field work. When first recorded by National Park Service archaeologists in the mid-1980s (Leap and Neal, 1992), the charcoal provided uncalibrated radiocarbon ages dating to between $1715 \pm 55$ B.P. 


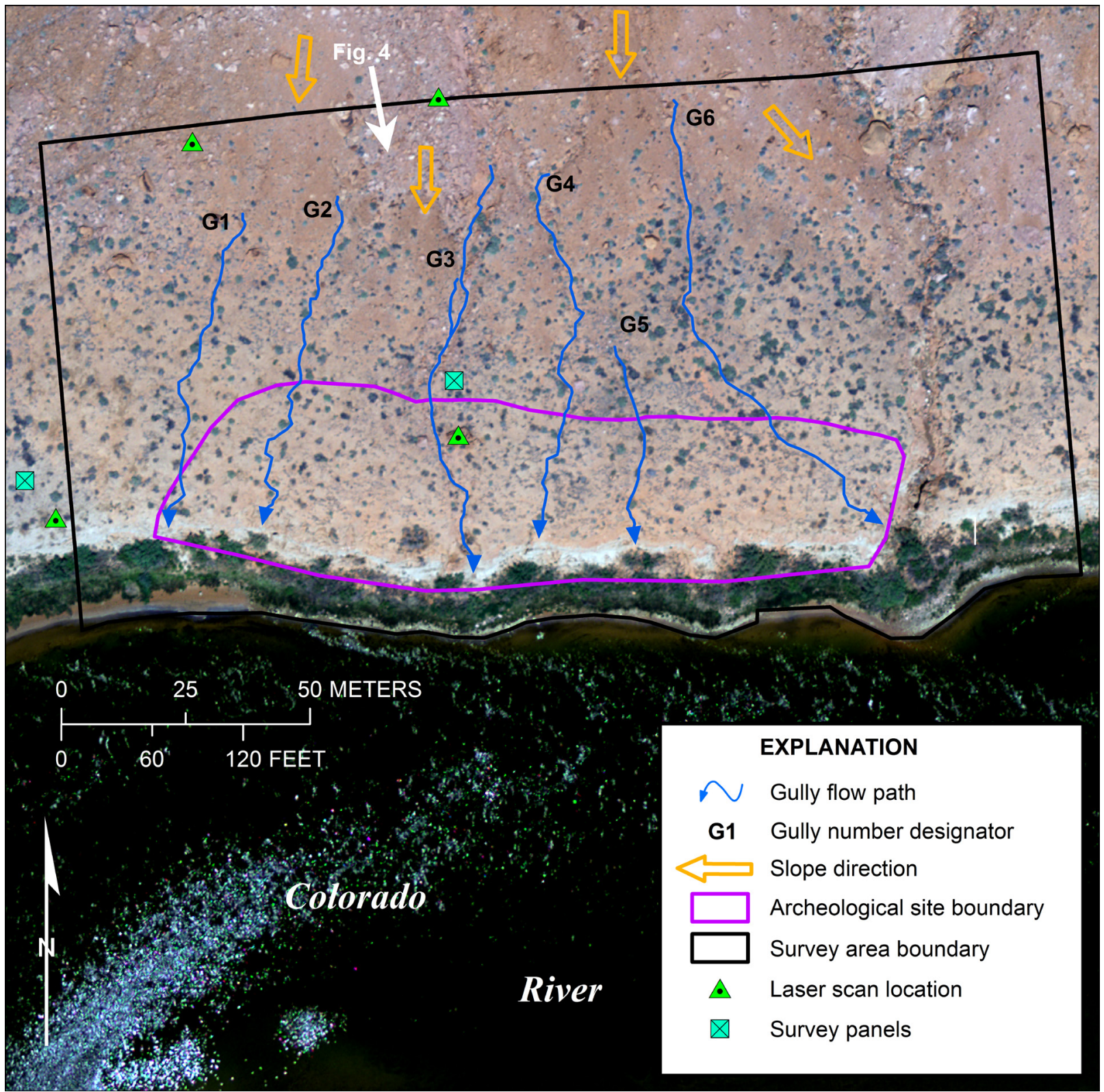

Figure 3. Site AZ:C:02:0032 survey map showing position of terrestrial lidar scanning locations, airborne lidar survey panels, and gully locations and flow paths. Three additional laser scan locations are positioned to the south and are not shown. White arrow indicates look angle of image in figure 4.

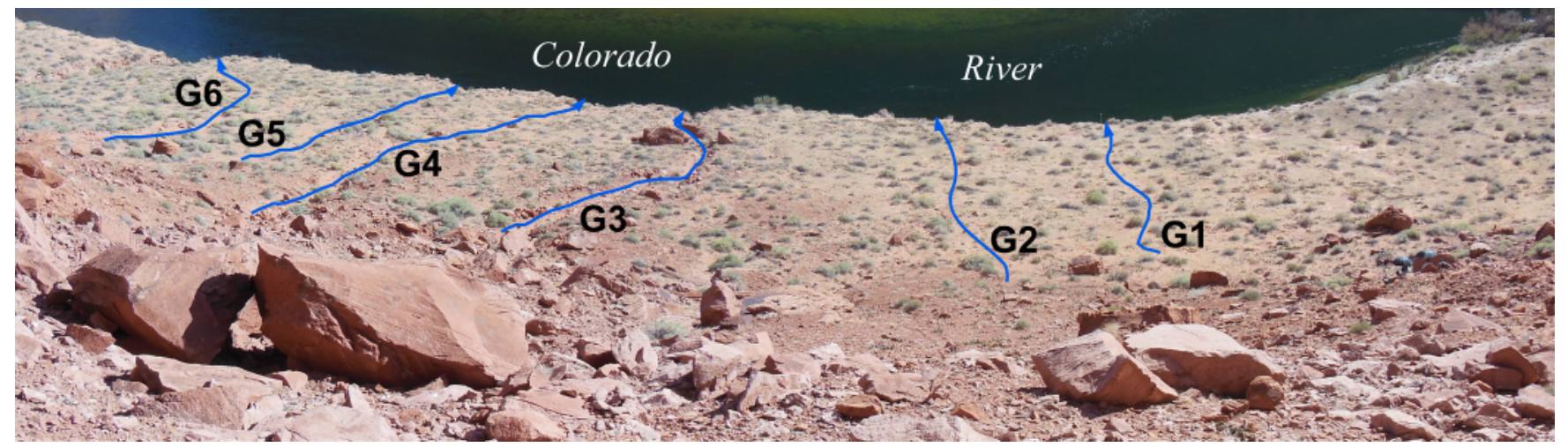

Figure 4. Site AZ:C:02:0032 survey area photo showing gully locations. Width of terrace along trace of gully G2 is $\sim 50 \mathrm{~m}$. View is to the south (see fig. 3). 
(Beta Analytic Sample \#57294, calibrated age 208-431 C.E.) and $3150 \pm 55$ B.P. (Beta Analytic Sample \#57295, calibrated age 1528-1292, B.C.E.); however, it was unclear to the excavators whether the charcoal staining was the result of natural burns or human activity. Additional investigations performed in 2005 concluded that the charcoal deposits at site AZ:C:02:0032 were indeed of human origin and that the two upstream sites investigated in 1999-2000 were even older and included more extensive buried materials than had previously been recognized (Anderson, 2006; Spurr and Collette, 2007). In addition, these researchers located two grinding slabs in slump deposits near the base of the terrace that appeared to have fallen out from an upper level of the cutbank, and they identified a probable hearth with a radiocarbon age of $2450 \pm 40$ B.P. (Beta Analytic Sample \#204748, 756-409 B.C.E.). Subsequent geoarcheological investigations by Pederson and others (2011) confirmed that the charcoal deposits were of human origin and that these, along with a hearth-shaped feature, date between $\sim 1000$ B.C.E. and 500 C.E. (that is, the pre-ceramic late Archaic and Basketmaker II periods). Further, they discovered a small number of ceramics in the uppermost level of the terrace that indicate a later use of this site during the Pueblo II period ( $1050-1150$ C.E.).

\section{Site AZ:C:02:0035}

Located just downstream of site AZ:C:02:0032, site AZ:C:02:0035 is a prehistoric ancestral Puebloan site located in the vicinity of several large talus boulders (figs. 5 and 6). The site is situated on a bedrock outcrop overlooking alluvial deposits adjacent to the Colorado River. Work by fluvial geomorphologists indicates that the terraces were deposited during the general Puebloan period (700-1200 C.E.) and prior to the Puebloan period ( $\sim 300$ C.E. to 2500 B.C.E.) (R. Hereford, unpub. data; Anderson, 2006.). In the immediate vicinity of the site there are higher, and presumably older, terrace remnants, consisting of undated gravel deposits of probable latePleistocene age, and even older patches of fine-grained fluvial deposits preserved under talus deposits (Anderson, 2006). The vegetation at the site is similar to that of site AZ:C:02:0032.

The archaeology here is typical of that found in temporary Puebloan camps in other parts of the Glen Canyon region (Adams and others, 1961). This site consists of two concentrations of artifacts associated with two large talus boulders. The style of the artifacts indicates that the site was probably occupied during the middle-late Pueblo II period ( 10501150 C.E.). One area consists of a low rock wall on the south side of a prominent talus boulder, with sparse ceramic pottery fragments and stone flakes scattered on the terrace surface to the west of the boulder. A small charcoal stain is present next to the low wall. Another area consists of a shallow shelter underneath a large overhanging talus boulder on the northeast edge of the site, with numerous stone flakes, cobble tools, and ceramic sherds scattered in the drainage immediately downslope of the shelter area.

\section{Site AZ:C:02:0075}

Site AZ:C:02:0075 is located within a narrow terrace surface between the Colorado River and adjacent bedrock cliffs (figs. 7 and 8). Two areas of artifacts and buried cultural features are located here and are separated by a large, deeply incised $(\sim 3 \mathrm{~m})$ gully. Vegetation along the terrace is similar to site AZ:C:02:0032 but also includes Yucca (Yucca sp.) bushes, and at the border of the study area along the river bank, Tamarisk trees (Tamarix ramosissima) that range from 1-2 $\mathrm{m}$ in height.

Artifacts occur on the terrace surface on either side of the arroyo and consist of stone flakes derived from a variety of lithic materials, some flaked core tools, bifacial tool fragments, a ground stone fragment, and a few pottery sherds dating to $\sim 1100-1200$ C.E., suggesting that the main occupation of this site occurred during the late Pueblo II or early Pueblo III periods. Two buried cultural features are exposed in the arroyo walls, one consists of an upright slab associated with a displaced grinding slab and the other is a basin-shaped fire pit consisting of a charcoal lens with fire-cracked limestone cobbles scattered on top. This latter feature yielded a radiocarbon date of $2040 \pm 40$ B.P. (Anderson 2006; Spurr and others, 2007). This date, and the position of the hearth approximately $90 \mathrm{~cm}$ below the present ground surface within deposits that correlate with Hereford's "sa" alluvium (dated in Grand Canyon to $\sim 300$ C.E. to 2500 BC; Hereford and others, 1995; 1996), indicates the presence of an earlier occupation predating the one on the terrace surface (Anderson, 2006; Spurr and Collette, 2007).

\section{Site AZ:C:02:0077}

Site AZ:C:02:0077 consists of a sparse scatter of flaked stone distributed on the surfaces of two adjoining fluvial terraces, with an erosional cutbank (terrace scarp) separating the two terrace surfaces (figs. 9 and 10). Several gullies are incised into the upper (older) terrace scarp and sediment from these gullies forms small alluvial fans on the lower (younger) terrace surface. The upper terrace is set some $100 \mathrm{~m}$ back from the edge of the river and riparian vegetation fronts much of the lower terrace. The distributed vegetation is qualitatively zoned by the two terrace surfaces with Tamarisk trees (Tamarix ramosissima), Drummond's goldenbush (Isocoma drummondii), and Fourwing saltbush (Atriplex canescens) found predominantly on the lower terrace. Fourwing saltbush (Atriplex canescens) is also found on the upper terrace, along with irregularly-spaced grasses, Mormon tea (Ephedra sp.) bushes, and Engelmann hedgehog cacti (Echinocereus engelmannii).

At least one basin-shaped charcoal feature is known to be present at this site and is still buried near the base of the terrace scarp at the south edge of the site. This feature, which appears to be a prehistoric hearth, was exposed during test excavations by the Navajo Nation Archaeology Department in 2005 , and yielded a radiocarbon age of $8180 \pm 40$ B.P. (9120 


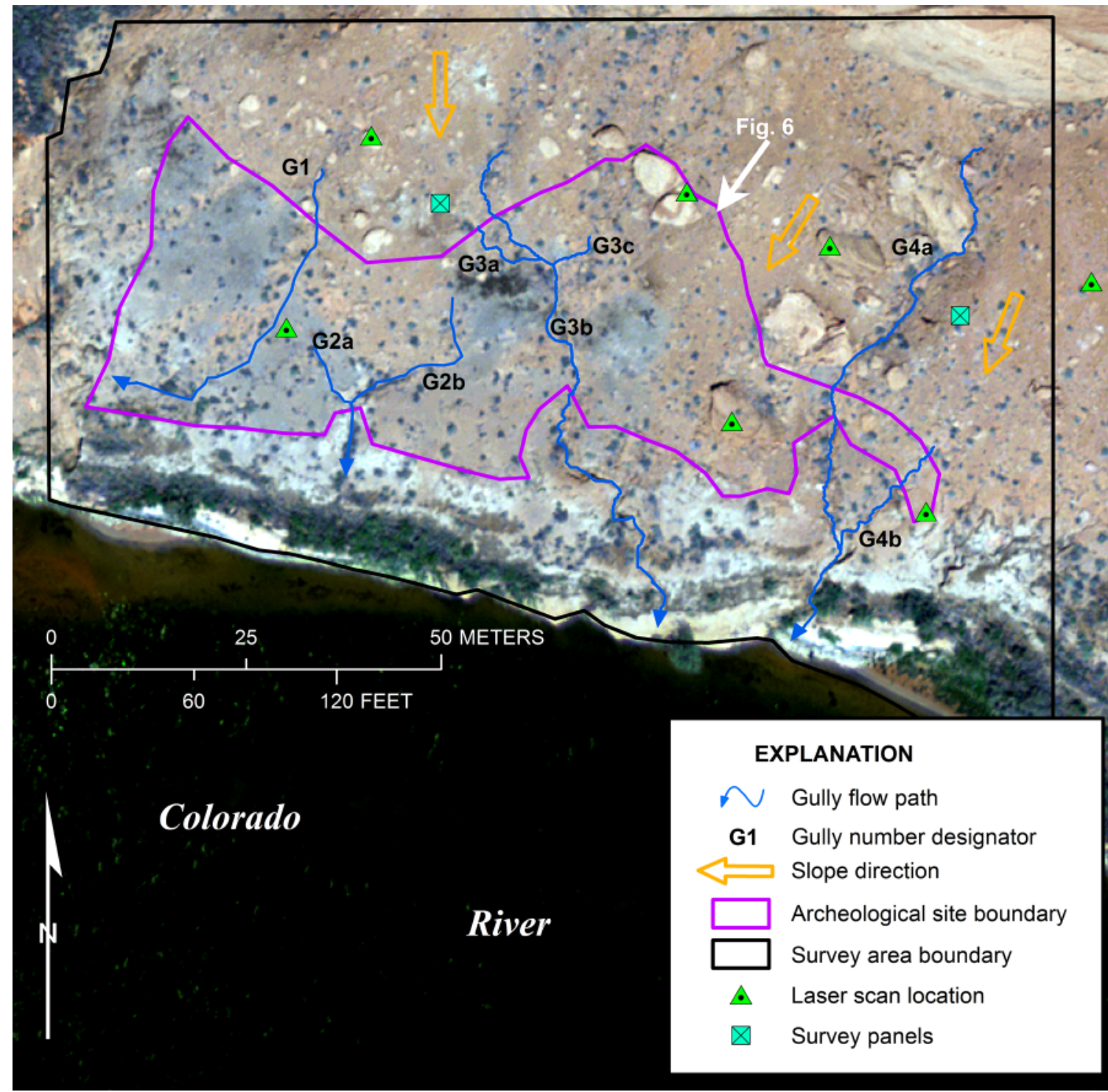

Figure 5. Site AZ:C:02:0035 survey map showing position of terrestrial lidar scanning locations, airborne lidar survey panels, and gully locations and flow paths. Three additional laser scan locations are positioned to the south and are not shown. White arrow indicates look angle of image in figure 6.

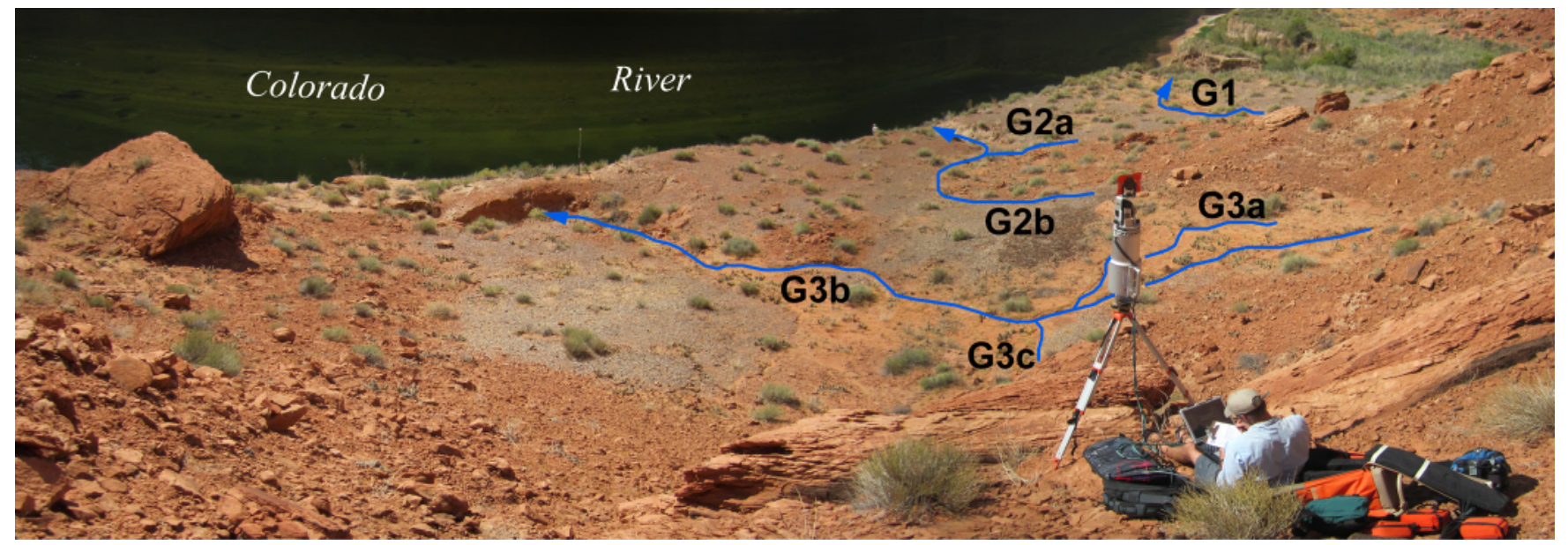

Figure 6. Site $A Z: C: 02: 0035$ survey area photo showing gully locations for $\mathrm{G} 1$ to $\mathrm{G} 3$. An additional gully (G4) is located out of view to the left of the photo. View is to the southwest (see fig. 5). 


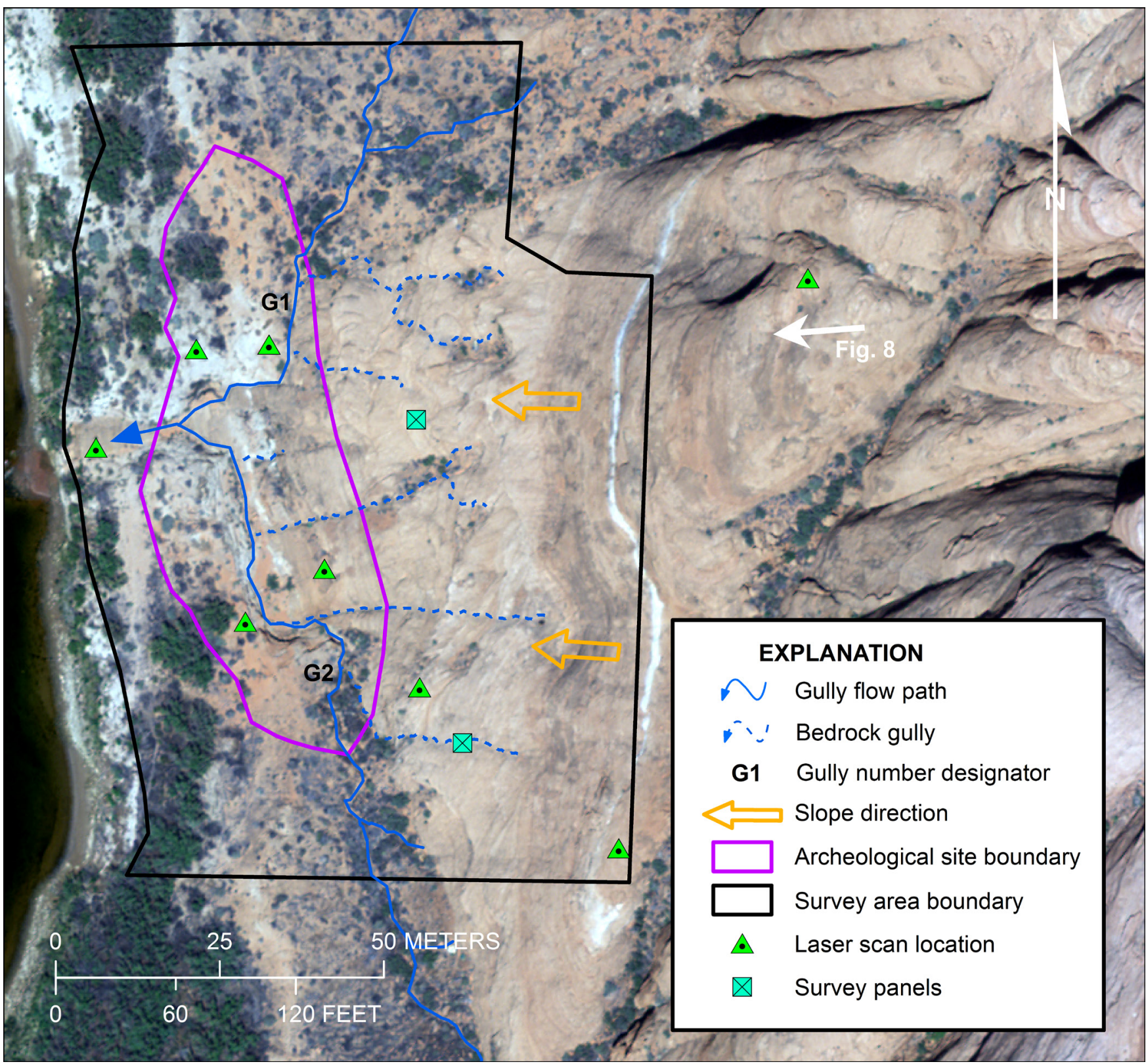

Figure 7. Site AZ:C:02:0075 survey map showing position of terrestrial lidar scanning locations, airborne lidar survey panels, and gully locations and flow paths. White arrow indicates look angle of image in figure 8.

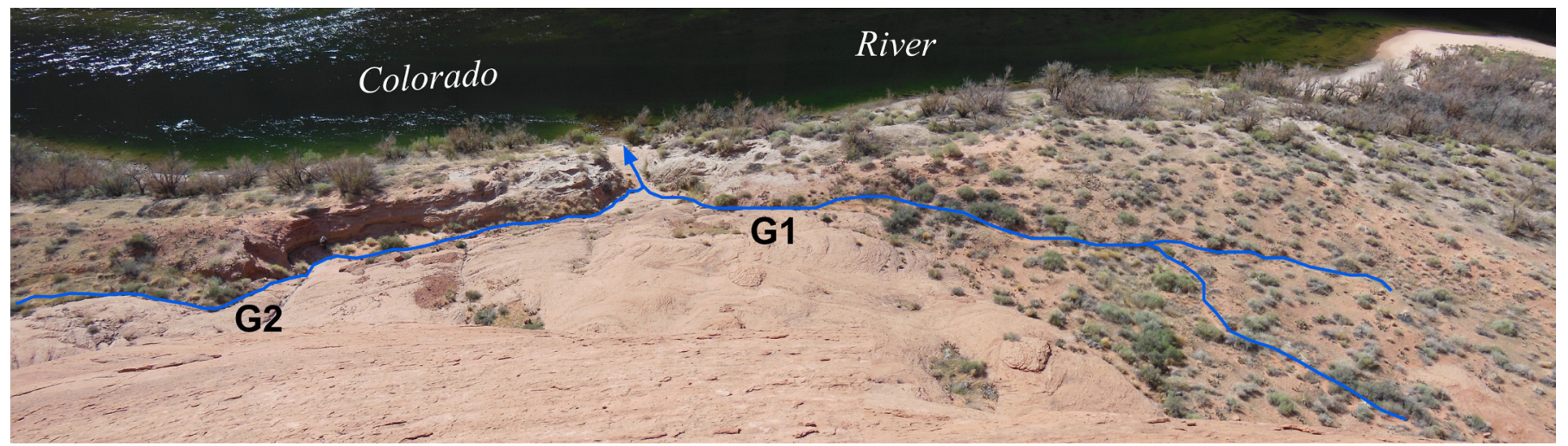

Figure 8. Site AZ:C:02:0075 survey area photo showing gully locations. Distance from "G2" label to confluence with gully $\mathrm{G} 1$ is $\sim 40 \mathrm{~m}$. View is to the west (see fig. 7). 


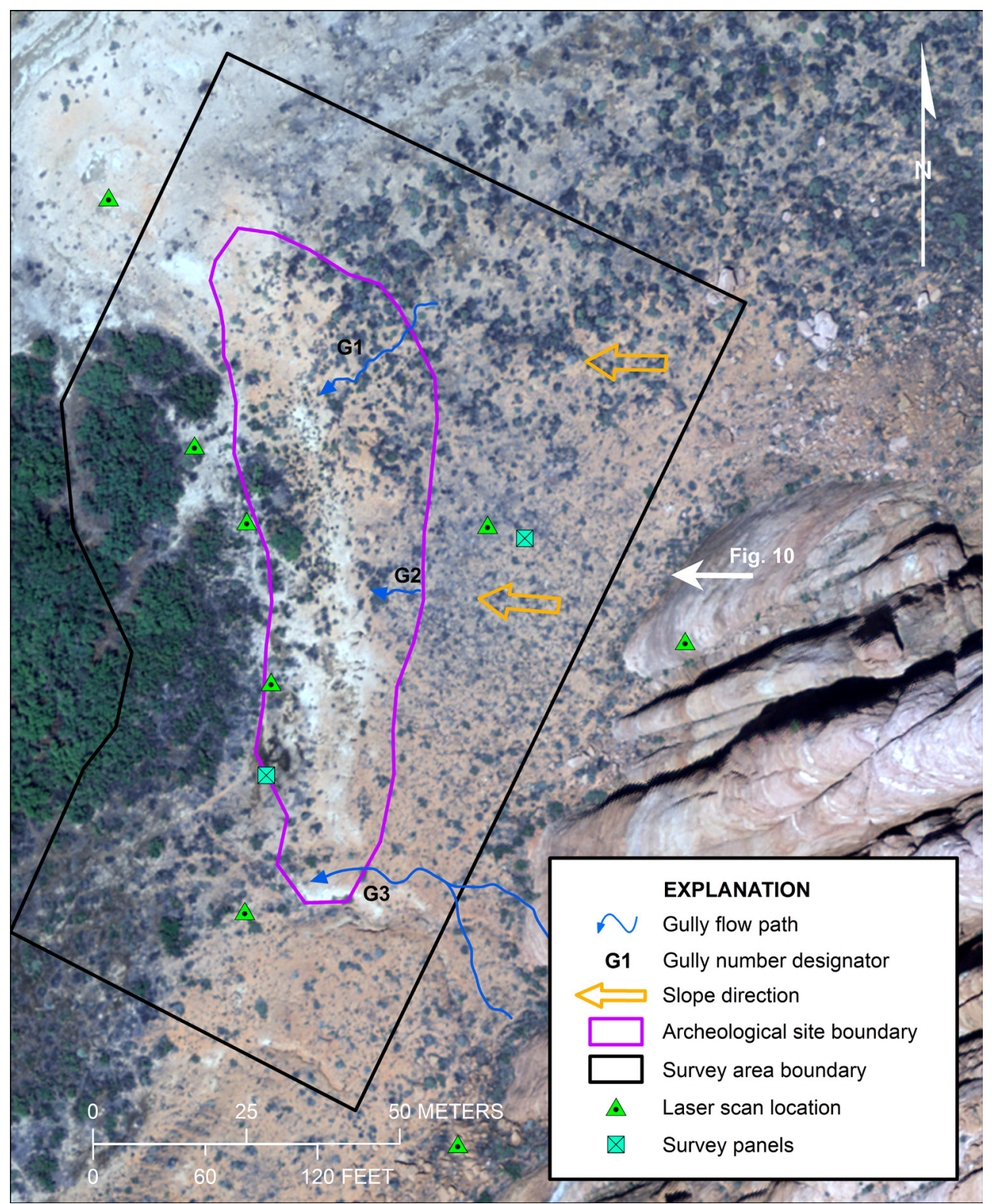

Figure 9. Site AZ:C:02:0077 survey map showing position of terrestrial lidar scanning locations, airborne lidar survey panels, and gully locations and flow paths. White arrow indicates look angle of image in figure 10.

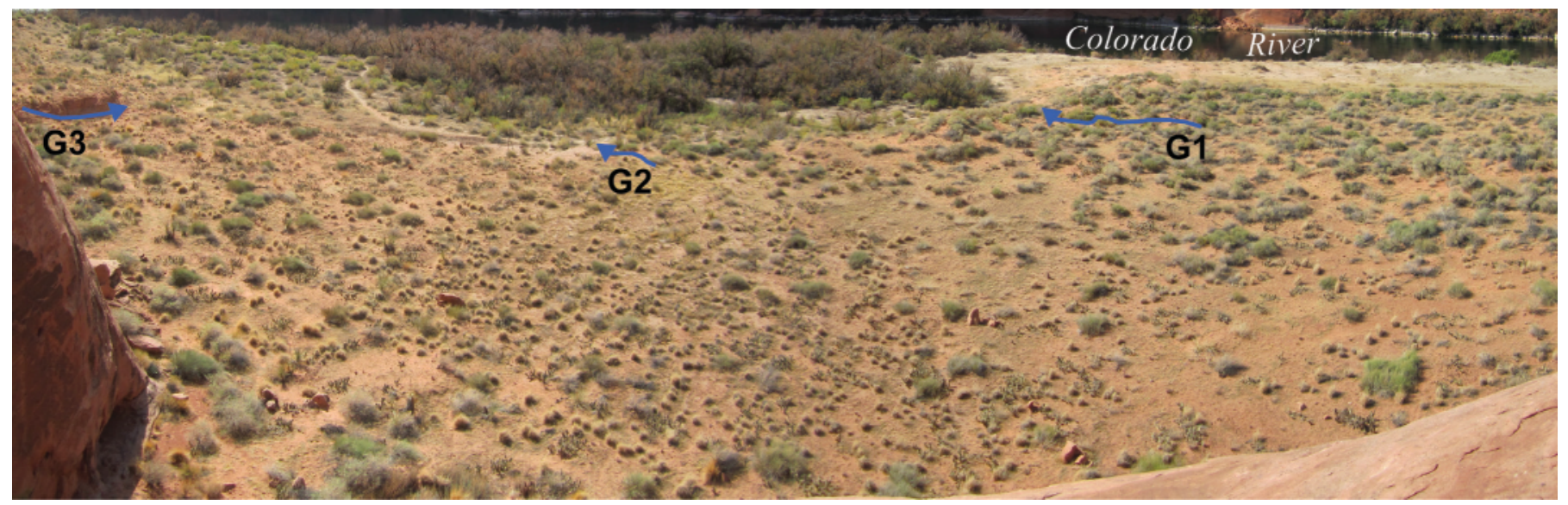

Figure 10. Site AZ:C:02:0077 survey area photo showing gully locations. Distance from bedrock cliff at lower left of image to the "G2" label is $\sim 40 \mathrm{~m}$. View is to the west (see fig. 9). 
calibrated yrs. B.P. or $\sim 7160$ B.C.E.) (Anderson 2006; Spurr and Collette, 2007). The position of this charcoal feature and the distribution of lithic artifacts suggest that most of the site is buried below the upper terrace surface, and that the artifacts found on the lower terrace eroded out of the upper terrace and are no longer in their original context. The potential for additional intact cultural deposits to be found within the upper terrace appears to be good, and the age of the charcoal feature suggests that these cultural remains may be some of the oldest currently known to occur in Glen Canyon.

\section{Methods}

We investigated the topography and geomorphology of the four selected archeological sites in Glen Canyon using terrestrial (ground-based) lidar, airborne lidar, and airborne automated digital photogrammetry. We also conducted data comparison analyses of these methods to determine inherent errors and to discern the overall utility of the data for recognizing particular features on the landscape. This was partly accomplished by use of total station methods to survey the horizontal and vertical positions of ground-targets visible in each data set.

\section{Terrestrial Lidar Surveys}

\section{Data Collection}

We collected high-resolution terrestrial lidar topographic data at the four selected sites from September 18-21, 2012. Each day, personnel and equipment were transported from the boat launch at Lees Ferry (fig. 1) to the sites using a motorboat. At each site, we focused our data collection on the terrain within and surrounding the designated archeological site boundaries (figs. 3, 5, 7, 9), as identified by previous mapping (Fairley and others, 1994; Spurr and Collette, 2007) and verified during the September 2012 field efforts.

The survey protocols used in this study were essentially identical to those developed for work in Grand Canyon National Park by Collins and others (2012). We used a Class 1 (eye safe), near-infrared, pulsed laser diode, Riegl Z420i terrestrial lidar laser scanner (fig. 11) mounted on either a standard or elevated tripod (as much as $2.6 \mathrm{~m}$ tall) at $7-8$ different laser scanner locations per site to obtain complete topographic data coverage of the terrain at each site. This laser collects pointcloud data at 8,000 points per second with a beam divergence of $0.014^{\circ}$ ( $\sim 25 \mathrm{~mm}$ at $100 \mathrm{~m}$ range) and minimum vertical and horizontal angle step widths of $0.004^{\circ}$. Typical maximum range for natural targets with 10 and 80 percent reflectivity is 350 and $1,000 \mathrm{~m}$, respectively, with $10 \mathrm{~mm}$ accuracy at $50 \mathrm{~m}$ range. In general, laser scanner locations were located within $50 \mathrm{~m}$ of the site topography. Only last returns from the laser were collected to identify the ground surface (rather than first returns, which might represent vegetative surfaces above the ground surface).

\section{Data Processing}

We processed the last return lidar data through a suite of registration, georeferencing, filtering, and surface-model generation techniques specific to terrestrial lidar data and used for data previously collected at archeological sites in Grand Canyon (Collins and others, 2012). This processing methodology is composed of an integrated workflow that has been demonstrated to ensure data quality and accuracy. Laser scan data from individual laser scanner locations were registered to one another in the field using Riegl RiScan Pro v.1.7.5 software (http://www. riegl.com/products/software-packages/riscan-pro/) and a temporary network of eight reflector control points $(10 \mathrm{~cm}$ tall, $10 \mathrm{~cm}$ diameter white reflective cylinders mounted on tripods) placed and scanned during our surveys throughout the archeological site areas. Using total station survey data collected at each laser scanner location and reflector control point, we georeferenced the data in the RiScan Pro software to obtain a best fit between the instrument locations and scanned control points, and their respective surveyed coordinates.

Data were exported as ASCII text format and imported to Maptek I-SiTE Studio v. 3.5.1 software (http://www.maptek. $\mathrm{com} /$ products/i-site/i-site_studio.html), where we filtered anomalous data (mainly atmospheric or hydrologic reflections) using maximum point separation and manual filtering algorithms. We created bare-earth point clouds and triangulated irregular network (TIN) surfaces (that is, with the data stripped of points representing vegetation) using a series of surface proximity and manual filtering algorithms (for additional details see Collins and others, 2012). Finally, these data were exported to ArcGIS

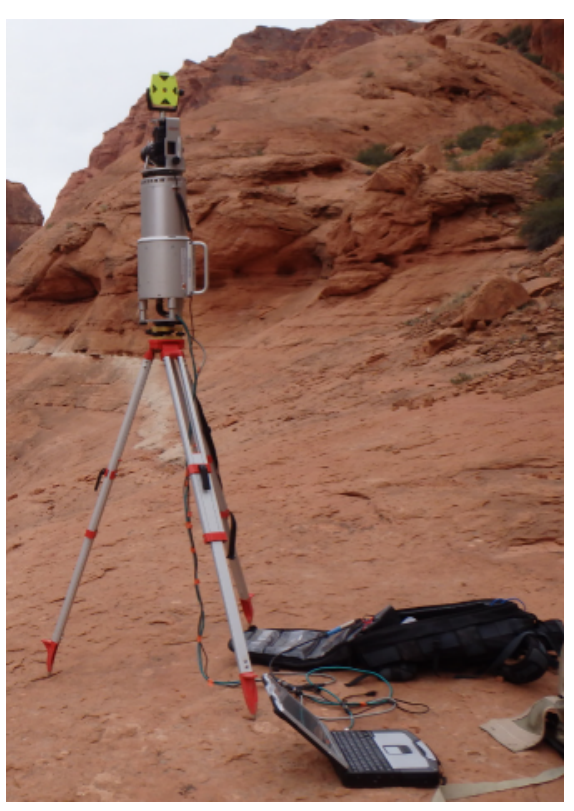

Figure 11. Photo showing terrestrial lidar data collection in Glen Canyon National Recreation Area. The laser (grey cylinder with handle) is connected to a laptop computer and batteries. A digital camera is mounted on top of the laser and provides color pixel data to the lidar point clouds. The total station prism (yellow and black backside shown) mounted on top of camera is used to georeference the instrument location. 
v. 10.1 (http://www.esri.com/software/arcgis/index.html) where $5 \mathrm{~cm}$ grid surfaces were created for data presentation.

\section{Error Assessment}

Positional errors in our terrestrial lidar data result from five factors: laser error, registration error, georeferencing error, survey error, and control network error (table 2). We present analyses of each of these for the horizontal and vertical components of error, and assume in all cases that errors are normally distributed about a mean. The vertical error budget typically forms the basis for performing landscape topographic change detection analysis between temporally consecutive data sets (for example, see Collins and others, 2012). Other types of error analysis budgets are possible (for example, see Collins and others, 2009) and may include a component of error from the registration process of multiple scans. For the data sets presented herein, we recognize that the registration error is important only when making internal measurements within the dataset; when comparing the accuracy of the entire data set to external data sources (such as digital elevation models constructed from aerial photos), the georeferencing error accounts for and greatly exceeds the registration error. Thus, for purposes of completeness, we present analysis results for registration error, but we do not include them in the overall error budget.

Laser errors $\left(E_{\text {laser }}\right)$ can be from either range or angular inaccuracies, and are typically reported as maximums by manufacturers. Third-party (non-manufacturer) empirical studies of precisely translated objects in both the range and cross-range directions provide independent and potentially more realistic estimates of accuracy. We used the results from one such study (Boehler and others, 2003), conducted at 10-60 m range with an identical laser instrument (Riegl Z420i) as our study, to establish the expected horizontal (range direction and lateral component of cross-range direction) and vertical (altitudinal component of cross-range direction) laser error. On the basis of the Boehler and others (2003) study, we estimated the laser error to be 0.3 and $0.7 \mathrm{~cm}$ for the horizontal and vertical components, respectively, both at the 95 -percent confidence interval.

Registration errors $\left(E_{r e g}\right)$ are a product of combining data from different scan locations (origins) into a single coordinate system. The root mean square (RMS) error of the best fit between reflector control point origins (that is, the center of the white reflective cylinder control points), scanned from different laser scanner locations and used to combine scans together, is a measurement of registration error. The three-dimensional 2-sigma (95-percent confidence interval) standard deviation registration error ranged from $0.4-2.1 \mathrm{~cm}$ for the network of eight control points at each surveyed archeological site and averaged $1.1 \mathrm{~cm}$ for all sites. Calculating the horizontal and vertical components of registration error requires an assumption that the error is evenly distributed between the $\mathrm{x}, \mathrm{y}$, and $\mathrm{z}$ directions (that is, the horizontal error is equal to the three-dimensional registration error multiplied by and the vertical error is equal to the three-dimensional error multiplied by, a valid assumption for this dataset). At the 95-percent confidence interval, we calculated the registration error to be 0.9 and $0.6 \mathrm{~cm}$ for the horizontal and vertical components, respectively.

Georeferencing errors $\left(E_{\text {georef }}\right)$ are associated with translating the locally registered laser origins and control point locations to a surveyed datum and projection coordinate system (for example, our data are referenced to the North American Datum of 1983 (NAD83), National Adjustment of 2011 (NA2011) and projected to Arizona Central Zone 0202 State Plane coordinates). This error is obtained by measuring the standard deviation between the local scan and control point origins, and the known surveyed coordinates. We calculated the average georeferencing error of the four sites to be 2.2 and $1.5 \mathrm{~cm}$ in the horizontal and vertical components, respectively, at the 95-percent confidence interval.

Surveying errors $\left(E_{\text {survey }}\right)$ are associated with how well the surveyed datum and projection coordinates are known as a result of the method in which they were measured (for example, total station or Global Positioning System, [GPS]). We surveyed all control and laser origins using total station methods (Hazel and others, 2008) from stable benchmark points (that is, nondeforming bedrock outcrops in tectonically stable areas). Multiple forward and reverse shots were collected for each target to ensure a high degree of precision in the measurements. Based on repeat total station measurements of 14 control and back sight points distributed throughout the surveyed areas, we calculated the georeferencing error to be 1.4 and $1.9 \mathrm{~cm}$ in the horizontal and vertical components, respectively, at the 95 -percent confidence interval.

Control network errors $\left(E_{\text {control }}\right)$ are associated with the known absolute accuracy of the benchmarks used to conduct the total station or GPS surveys used for georeferencing. When performing change detection between consecutively collected lidar data sets, the control network error can be ignored if identical benchmarks were used for the total station or GPS surveys. However, when overlaying the lidar data on other data products, such as airborne lidar or aerial photographs, this error must be accounted for and can, in fact, dominate the overall error budget.

Table 2. Error assessment for maximum errors in terrestrial lidar data.

[All values in centimeters]

\begin{tabular}{lcccccrr}
\hline \multicolumn{1}{c}{ Error type } & Laser error & $\begin{array}{c}\text { Registration } \\
\text { error }^{1}\end{array}$ & Georef. error & $\begin{array}{c}\text { Total station } \\
\text { survey error }\end{array}$ & $\begin{array}{c}\text { Control net- } \\
\text { work error }\end{array}$ & $\begin{array}{c}\text { Total relative } \\
\text { error }\end{array}$ & $\begin{array}{c}\text { Total absolute } \\
\text { error }\end{array}$ \\
\hline Horizontal & 0.3 & 0.9 & 2.2 & 1.4 & 6.2 & 2.6 & 6.7 \\
Vertical & 0.7 & 0.6 & 1.5 & 1.9 & 10.8 & 2.6 & 11.1 \\
\hline
\end{tabular}

${ }^{1}$ Registration error is not included in the total errors-see previous discussion. 
We based the control network errors on results from a canyonwide study of established control points (Hazel and others, 2008). This study indicates that the 95 -percent confidence interval accuracy of the types of benchmarks used for total station and back-sight positioning (that is, tertiary river control points; Hazel and others, 2008) is 6.2 and $10.8 \mathrm{~cm}$ for the horizontal and vertical components, respectively.

We calculated the overall positional error $\left(E_{\text {total }}\right)$ in the terrestrial lidar data by treating the four components of overall error independently (that is, excluding the internal registration error). The errors, therefore, are additive, resulting in a conservative (worst-case) RMS error estimate:

$$
E_{\text {total }}=\sqrt{{E_{\text {laser }}{ }^{2}+E_{\text {georef }}^{2}+E_{\text {survey }}^{2}+E_{\text {control }}^{2}}^{2}}
$$

The absolute error in the terrestrial lidar data is 6.7 and $11.1 \mathrm{~cm}$ for the horizontal and vertical components, respectively; this sets the accuracy of the data relative to other data sources. Ignoring absolute control network positional errors (that is, $E_{\text {control }}=0$ ) results in an estimated relative accuracy of $2.6 \mathrm{~cm}$ each for the horizontal and vertical components; this sets the estimated vertical change detection threshold at $5.2 \mathrm{~cm}$ (conservatively calculated as twice the single relative positional error) for future surveys using the same benchmarks for total station positioning.

We note that these error assessments are based on maximum possible errors in the data sets. It is highly unlikely that all errors are independent, nor that they are always additive in the same direction. A more common degree of accuracy might only include the errors at the 68-percent confidence interval in which case errors would be roughly half of those reported for the maximum (that is, for local change detection that ignores control network error, the vertical error would be $1.3 \mathrm{~cm}$ and the resultant vertical change detection threshold for two similarly collected data sets would be $2.6 \mathrm{~cm}$ ).

\section{Airborne Lidar Survey}

\section{Data Collection}

Airborne lidar was collected on July 10, 2013, by Fugro Aerial \& Mobile Mapping, Inc. (FAMM), under contract with the USGS. Approximately $13.7 \mathrm{~km}$ (8.5 river miles) were flown of the Glen Canyon area from approximately river mile (RM) -6 to $\mathrm{RM}-14.5$, as measured using negative numbers upstream from Lee's Ferry (RM 0). The data encompassed the entire river channel (excluding water areas where no lidar returns were obtained) and canyon bottom from canyon wall to canyon wall, and included the area of the four archeological sites where terrestrial data were collected. FAMM used the helicopter-based FLI-MAP 400 airborne lidar system (fig. 12, http://www.flimap.com/uploads/FLIMAPTech.pdf), with laser pulse rates between 150,000-250,000 pulses/second, up to four returns per pulse recorded, and $60^{\circ}$ laser swath width. Flying at $\sim 200 \mathrm{~m}$ mean altitude above ground surface, the data collection required five independent flight passes to capture the full width of the canyon bottom. Lidar spot diameter for this system, at this altitude, is $\sim 10 \mathrm{~cm}$. Forward speed was $\sim 20$ $\mathrm{m} / \mathrm{s}$, providing a point density of $\sim 54$ points $/ \mathrm{m}^{2}$ for a single swath. In general, adjacent swaths overlapped by 50 percent, providing a final point density of more than 100 points $/ \mathrm{m}^{2}$,

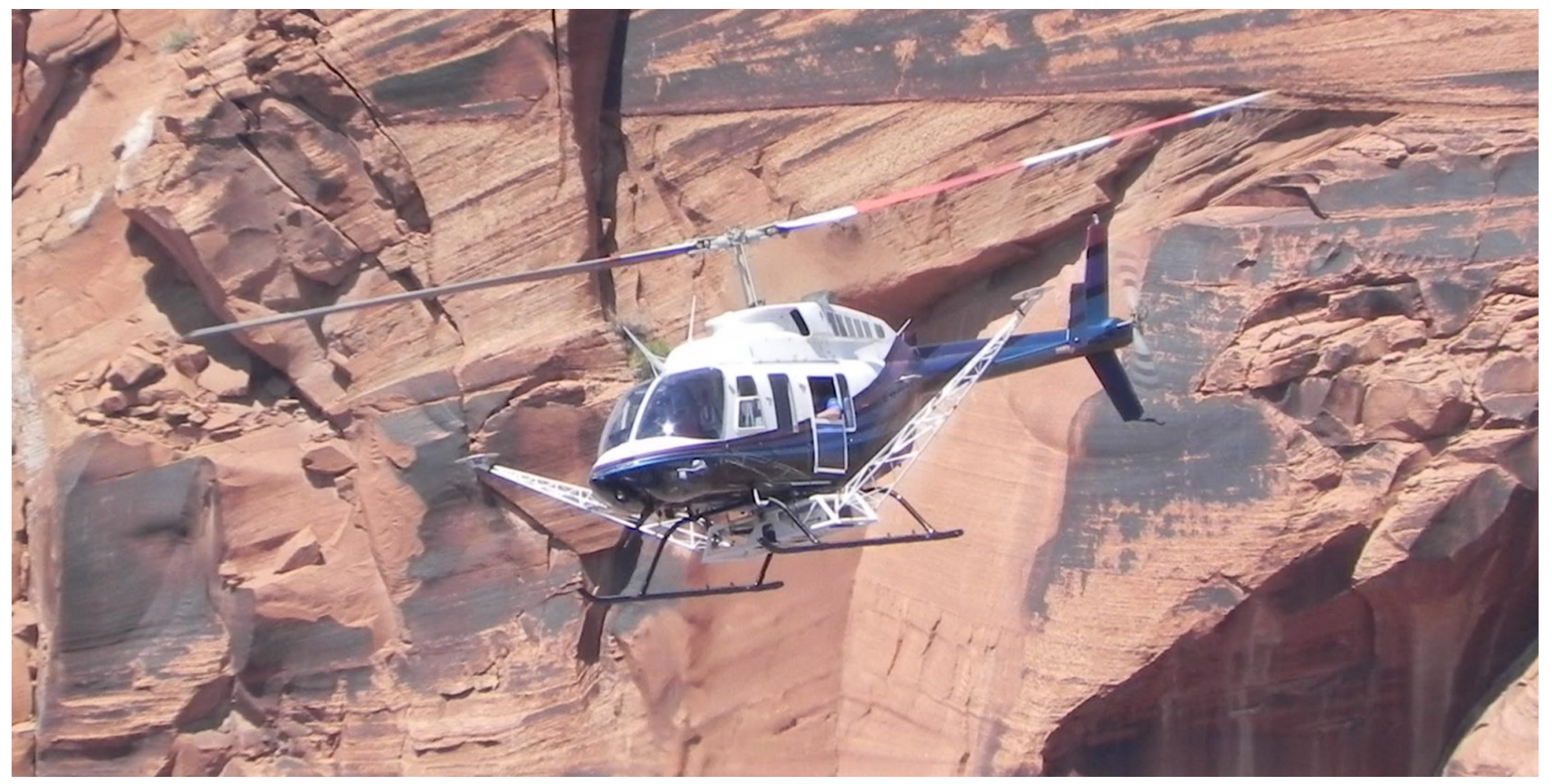

Figure 12. Photo showing airborne lidar data collection in Glen Canyon National Recreation Area. Image courtesy of Fugro Aerial \& Airborne Mapping, Inc. 
with the exception of the bordering half-swath-widths on either side of the canyon. The system collected returns from fore, aft, and nadir-looking lasers, and thus provided a greater assortment of scan angles than either an entirely nadir- or obliquescanning system.

\section{Data Processing}

Data registration and georeferencing procedures for the FLI-MAP system were performed internally within the system using onboard INU (Inertial Navigation Unit) data and realtime kinematic GPS data from three independent base stations located on the canyon rims and occupied by FAMM during the lidar acquisition. Data post-processing used the Fugro FLIP7 software program (http://www.flimap.com/site295.php) and only involved data verification and data checks between adjacent swath widths; no additional point-matching algorithms were applied.

\section{Error Assessment}

The reported maximum relative horizontal and vertical errors of individual points within the data set are both $5 \mathrm{~cm}$ at the 95-percent confidence interval (table 3 ). The reported maximum absolute horizontal and vertical errors (that is, in real-world coordinate space) are $8 \mathrm{~cm}$ and $5 \mathrm{~cm}$, respectively, also measured at the 95-percent confidence interval (http:// www.flimap.com/uploads/FLIMAPTech.pdf). Absolute errors are larger in the horizontal direction due to the constantlychanging horizontal position of the helicopter; the vertical errors are smaller because the helicopter maintained a fairly constant altitude during data collection.

Table 3. Error assessment for maximum errors in airborne lidar point data'.

[All values in centimeters]

\begin{tabular}{lcc}
\hline \multicolumn{1}{c}{ Error type } & Total relative error & Total absolute error \\
\hline Horizontal & 5.0 & 8.0 \\
Vertical & 5.0 & 5.0 \\
\hline
\end{tabular}

${ }^{1}$ As reported by the contractor and equipment specifications.

\section{Airborne Automated Digital Photogrammetry}

\section{Data Collection}

Digital surface models (DSMs) were produced from airborne automated digital photogrammetry data acquired under contact with Fugro EarthData Inc. (Fugro; http://www. fugroearthdata.com/) between May 25 and June 2, 2009, for a $450 \mathrm{~km}$ length of Glen and Grand Canyon (Davis, 2012), with the Glen Canyon data presented herein collected on May 25, 2009. Stereo-panchromatic imagery was collected in conjunction with high-resolution multi-spectral imagery using a Leica ADS40 SH-52 sensor from a fixed-wing aircraft flying at $3,048 \mathrm{~m}$ altitude. The sensor simultaneously collects images from fore, aft, and nadir lenses, providing stereo pairs for each imaged surface. Data were acquired at a steady Colorado River discharge of $227 \mathrm{~m}^{3} / \mathrm{s}\left(8,000 \mathrm{ft}^{3} / \mathrm{s}\right)$.

\section{Data Processing}

The stereo-image collection was processed by Fugro EarthData Inc. Fugro determined the relative image position using tie points between flight line images, and absolute position from the airborne GPS/INU and ground GPS base stations. A final aerotriangulation block was produced using ground control for each panchromatic data set for each flight line. The DSM was derived from the panchromatic imagery using Pixel Factory software (http://www.astrium-geo.com/en/161-pixelfactory). The DSM data have

$1 \mathrm{~m}$ cell resolution with vertical ellipsoid heights reported to the nearest $10 \mathrm{~cm}$ (but are only accurate to the nearest $30 \mathrm{~cm}$ - see following error assessment section), and are sectioned into U.S. Geological Survey map quadrangles. The data were not initially processed to remove effects of vegetation or other surface cover on topographic elevation values. However, to minimize these effects, we replaced pixels that contained vegetation canopies identified in classification of the coincidentally collected and co-registered multispectral imagery, with elevations interpolated from surrounding bare-ground surfaces.

\section{Error Assessment}

Horizontal and vertical accuracy of the DSM data was assessed by comparison with 125 ground control points distributed over the $450 \mathrm{~km}$ length of data collection (Davis, 2012; P. Davis, USGS, written commun., 2013) and surveyed with total station methods (table 4). These errors were normally distributed with an initial $38 \mathrm{~cm}$ vertical offset, but were subsequently adjusted, resulting in a final dataset with relative vertical RMS error of $30 \mathrm{~cm}$ (P. Davis, USGS, written commun., 2013). The relative positional (horizontal) accuracy was determined to be $19 \mathrm{~cm}$ (Davis, 2012). For calculation of absolute errors (relative to outside of the total station control network), we calculate the RMS error of the relative errors with those from the total station methods utilized for surveying the ground control points. These include the total station error reported previously (table 2 ) and the average errors $(2.1 \mathrm{~cm}$ horizontal and $5.3 \mathrm{~cm}$ vertical) for the primary river control points used in the total station network (Hazel and others, 2008). Resulting absolute errors are 19 and $31 \mathrm{~cm}$ in the horizontal and vertical directions, respectively.

\section{Total Station Surveys of Panel Locations}

To measure the vertical accuracy of the digital topographic data relative to each other, we deployed square 1.2 by $1.2 \mathrm{~m}$ black and white iron-cross-type survey panel targets (fig. 13) at eight locations (two each at the four archeological sites 
Table 4. Error assessment for maximum errors in airborne automated digital photogrammetry.

[All values in centimeters]

\begin{tabular}{lcccc}
\hline Error type & $\begin{array}{c}\text { Total } \\
\text { relative } \\
\text { error }\end{array}$ & $\begin{array}{c}\text { Total } \\
\text { station } \\
\text { survey } \\
\text { error }\end{array}$ & $\begin{array}{c}\text { Control } \\
\text { network } \\
\text { error }^{2}\end{array}$ & $\begin{array}{c}\text { Total } \\
\text { absolute } \\
\text { error }\end{array}$ \\
\hline Horizontal & 19 & 1.4 & 2.1 & 19 \\
Vertical & 30 & 1.9 & 5.3 & 31 \\
\hline
\end{tabular}

${ }^{1}$ As reported by Davis (2012) and P. Davis (USGS, written commun.. 2013).

${ }^{2}$ As reported by Hazel and others (2008)

investigated herein). We chose panel locations that were free of vegetation and topographically smooth. The center and four corners of each panel were surveyed using total station survey methods. Overall accuracy of the panel data is identical to that for the survey and control errors $\left(E_{\text {survey }}\right.$ and $\left.E_{\text {control }}\right)$ previously reported for the terrestrial lidar data error assessment (table 2). Assuming independent relations for these two components results in total absolute horizontal and vertical errors of 6.4 and $11.0 \mathrm{~cm}$, respectively for the total station data of the targets.

Within the lidar processing software, we constructed two 0.5 by $0.5 \mathrm{~m}$ surfaces over the horizontal center of each surveyed panel location and moved each square surface to the best fit of the terrestrial and airborne point-cloud datasets in that location. Measuring the centroid of the best-fit square surface results in an estimate of the surface elevation of each lidar data set at each panel location. The vertical accuracy of the DSM data was assessed by extracting the elevations of the nearest neighbor DSM pixel for each panel location. We compared these elevations to generate an empirical estimate of the agreement between the data sets (presented in the subsequent Topographic Analysis section).

\section{Results}

\section{Terrestrial Lidar Data}

Terrestrial lidar topographic data at each archeological site (ranging in area from 2,200-4,700 $\mathrm{m}^{2}$, as defined by the site boundaries shown in figs. 3, 5, 7, and 9) include several million points; for most sites $\sim 70$ percent are of the ground (non-vegetative) surface (table 5). Site AZ:C:02:0077 has a lower ground point percentage ( $\sim 33$ percent) due to dense vegetation within the site boundary. Overall point density ranges from $900-6,300$ points $/ \mathrm{m}^{2}$. Data density is highest near laser scan locations; data density is lowest at the bottom of gullies, and behind vegetation and boulders that partially obscure the ground surface. In areas of dense vegetation, the point density can approach only a few points per square meter. However, average point spacing within most of the archeological site

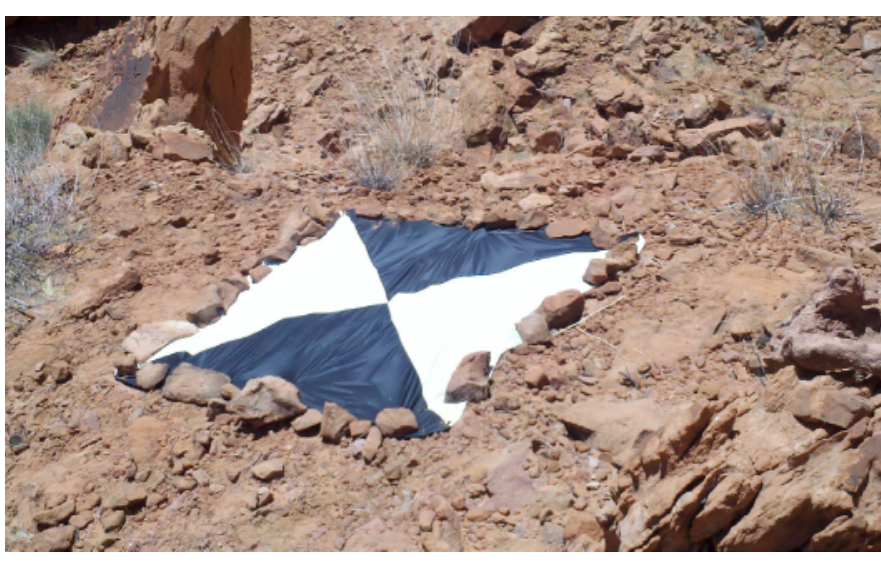

Figure 13. Photo showing iron-cross-type survey panel used for lidar data accuracy and point density comparison.

boundaries is on the order of $1-5 \mathrm{~cm}$, providing a sufficiently high resolution data set to construct detailed topographic surfaces of most small-scale (centimeter-scale) geomorphological features. Bare-earth (that is, vegetation-filtered) surface maps using $5 \mathrm{~cm}$ gridded (DEM - digital elevation model) points and $5 \mathrm{~cm}$ TIN (triangulated irregular network) points for each site (figs. 14-21) showcase the high resolution of the data. Gullies are clearly visible traversing the relatively flat topography of the sites, as are near-vertical terrace scarps bordering some of the sites. In the point data, boulders, vegetation, and other small features are easily distinguished (for example, fig. $22 A$ ), although all sides of a particular object are not always captured in the same detail due to the varying look-angles at which the terrestrial data was collected (for example, see the gully bottom in fig. 23A). However, we were able to visually identify most objects in the three-dimensional point-cloud data that measured at least $15 \mathrm{~cm}$ in their minimum dimension.

\section{Airborne Lidar Data}

Airborne lidar topographic data at each archeological site (as defined identically as for the terrestrial data analysis) include several hundred thousand points per site; for most sites $\sim 85$ percent of points are of the ground (non-vegetative) surface (table 6). This provides a ground point density at each site ranging from $50-130$ points $/ \mathrm{m}^{2}$. Highest point density occurs at sites with large expanses of bedrock (AZ:C:02:0075); lowest point density occurs at sites with dense vegetation cover (AZ:C:02:0077) and at site AZ:C:02:0035 where only one airborne flight line was collected (that is, no overlap in flight lines at the boundary of the survey). Average point spacing is on the order of 10-15 cm within each archeological site boundary. Bare-earth TIN-based surface maps (for example, fig. $23 B$ ), constructed using identical vegetation-filtering algorithms as for the terrestrial lidar data, compare well with the terrestrial-lidar-based TIN maps (compare with fig. 23A) and demonstrate the effect of both different point density and data collection look-angle between the data sets. Whereas point density is typically less in the airborne data, the difference is 


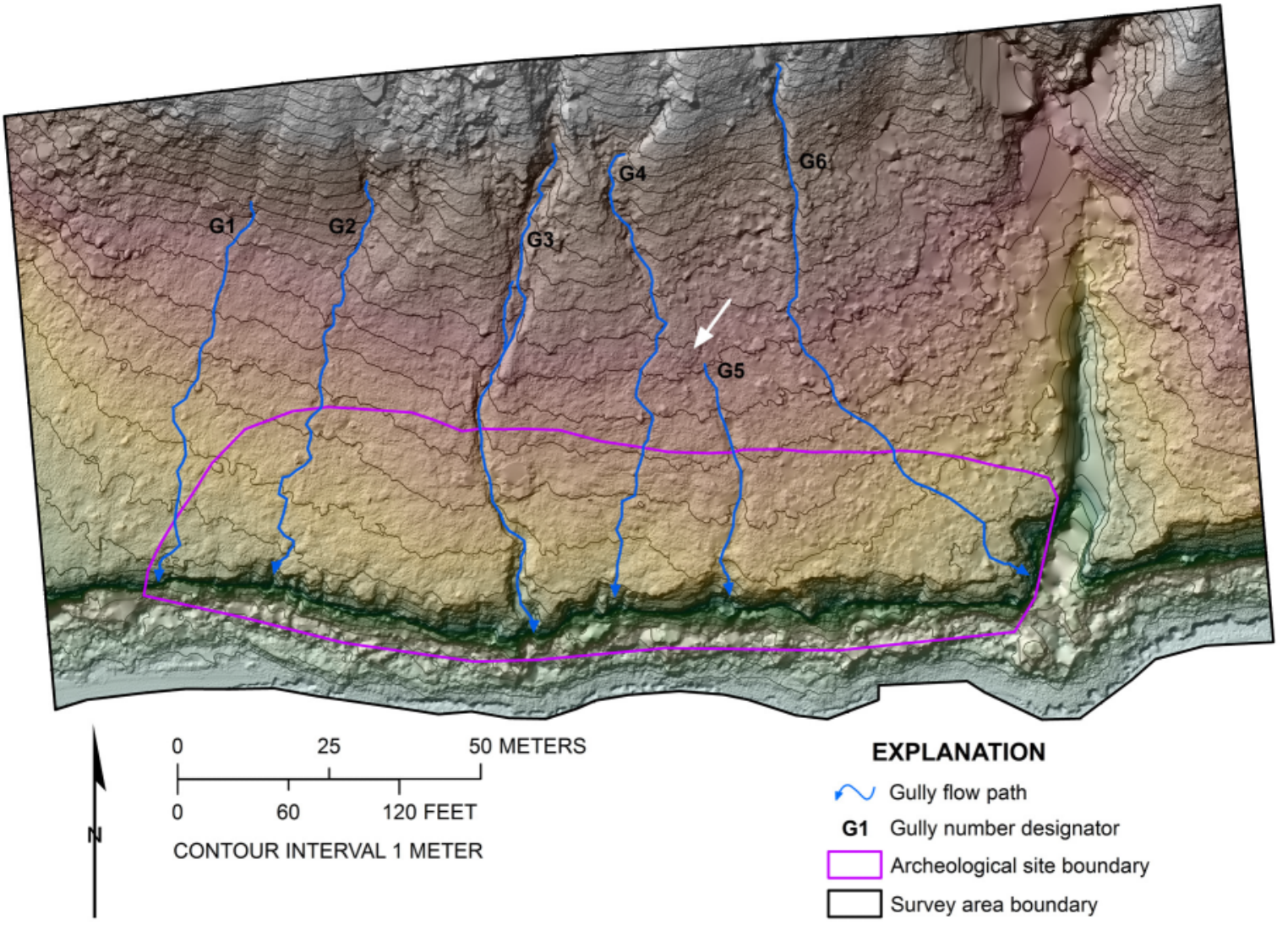

Figure 14. Site AZ:C:02:0032-Terrestrial lidar $5 \mathrm{~cm}$ gridded topographic surface map with $1 \mathrm{~m}$ contours and gully locations. Gullies are cross-referenced with geomorphology data presented in table 8. White arrow identifies location of lobe-shaped convex feature at top of gully $\mathrm{G} 5$ discussed in text.

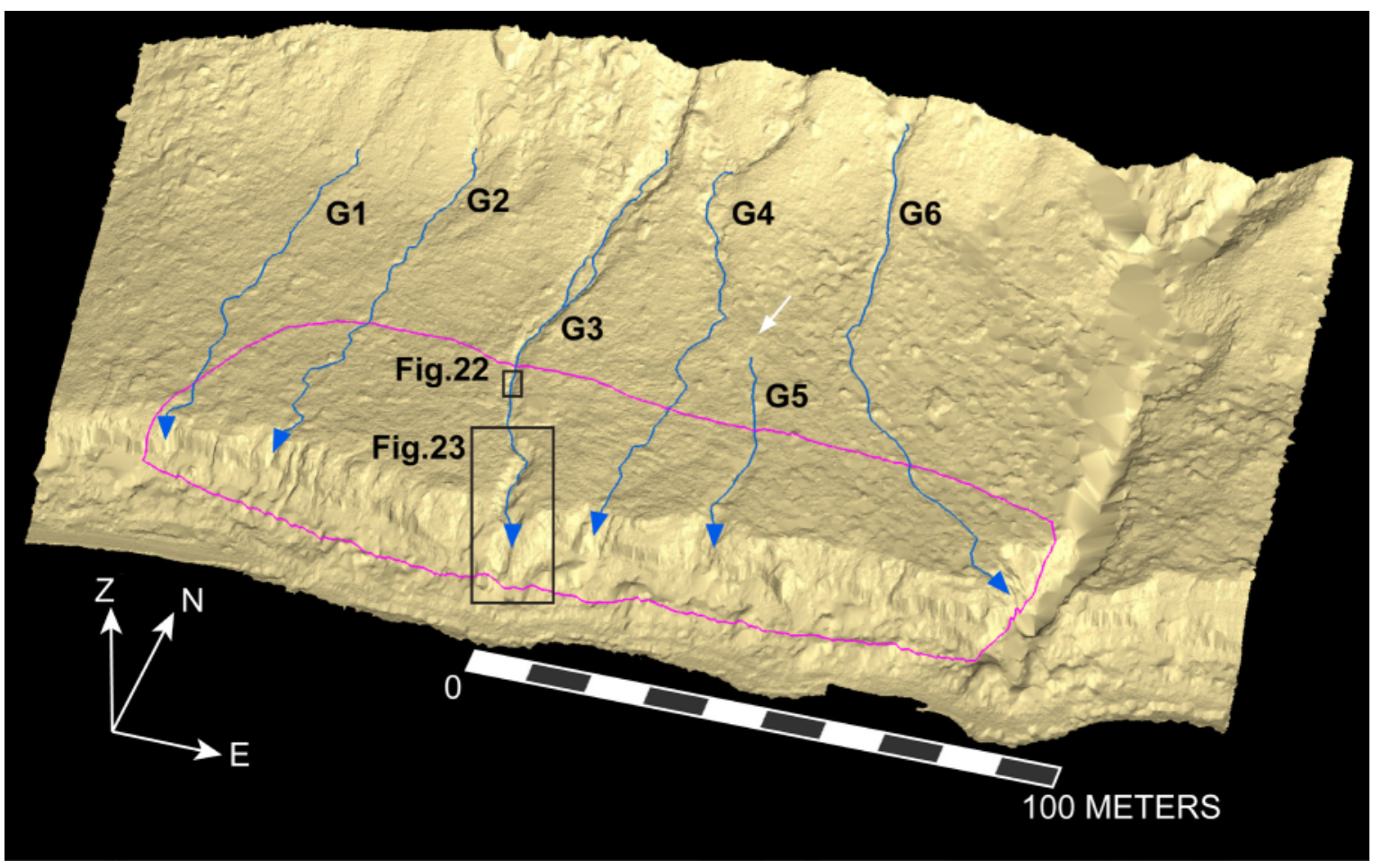

Figure 15. Site AZ:C:02:0032 site boundary (purple line)_Terrestrial lidar triangulated irregular network-based topographic surface map showing locations of gullies (blue lines). Gullies are cross-referenced with geomorphology data presented in table 8. White arrow identifies location of lobe-shaped convex feature at top of gully G5 discussed in text. 


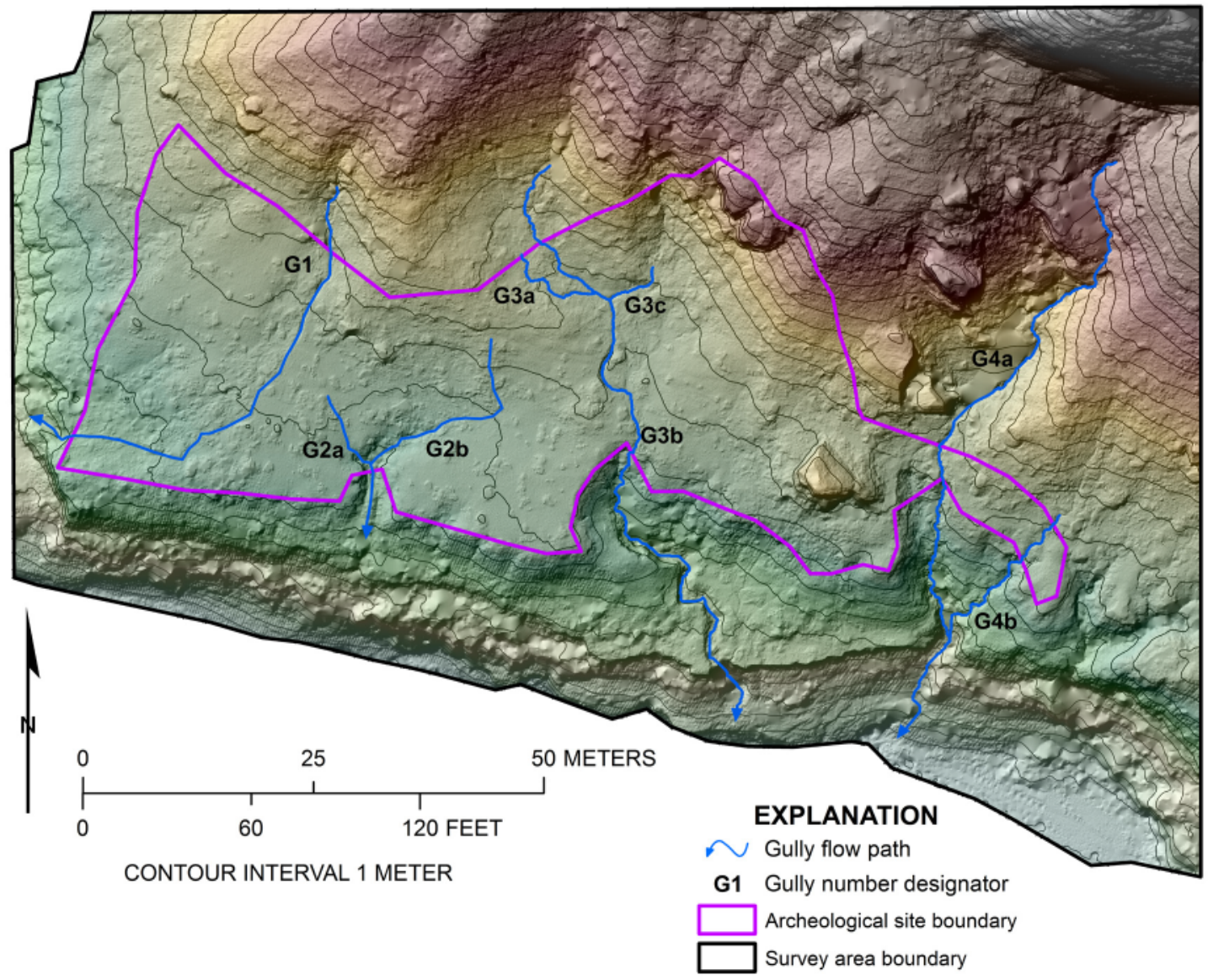

Figure 16. Site AZ:C:02:0035-Terrestrial lidar $5 \mathrm{~cm}$ gridded topographic surface map with $1 \mathrm{~m}$ contours and gully locations. Gullies are cross-referenced with geomorphology data presented in table 9.

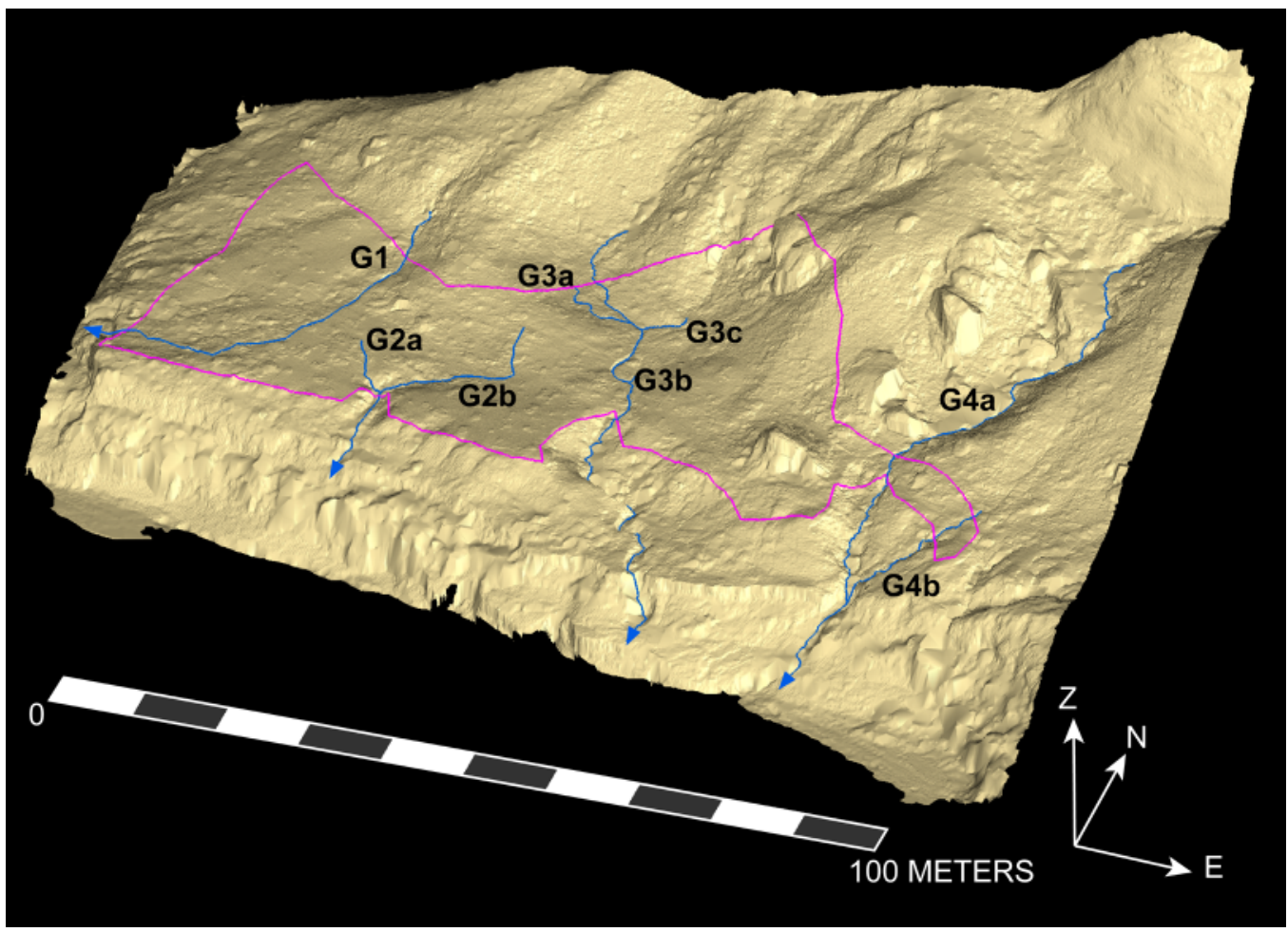

Figure 17. Site AZ:C:02:0035 (purple line)—Terrestrial lidar triangulated irregular network-based topographic surface map showing locations of gullies (blue lines). Gullies are cross-referenced with geomorphology data presented in table 9. 


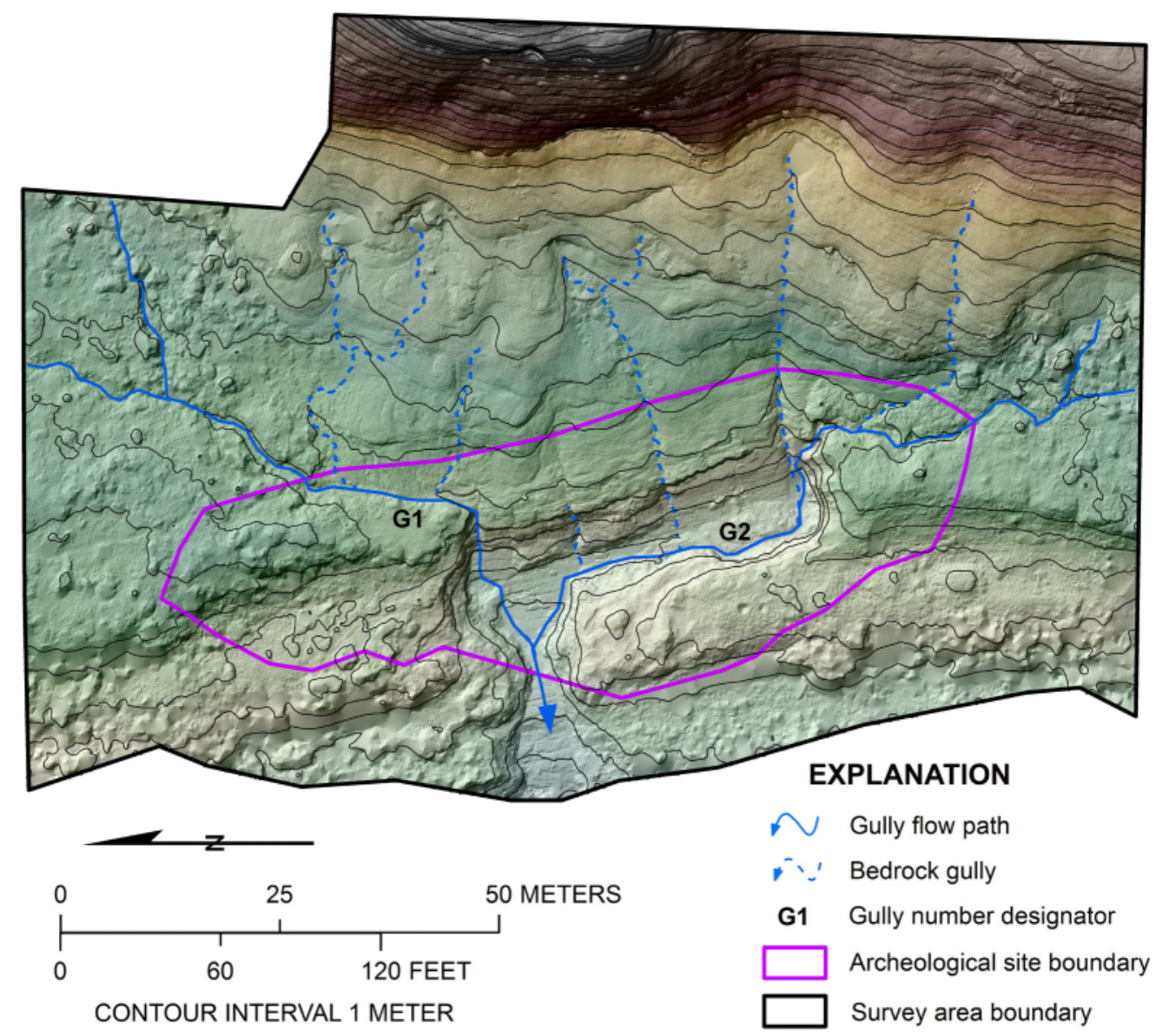

Figure 18. Site AZ:C:02:0075-Terrestrial lidar $5 \mathrm{~cm}$ gridded topographic surface map with $1 \mathrm{~m}$ contours and gully locations. Gullies are cross-referenced with geomorphology data presented in table 10.

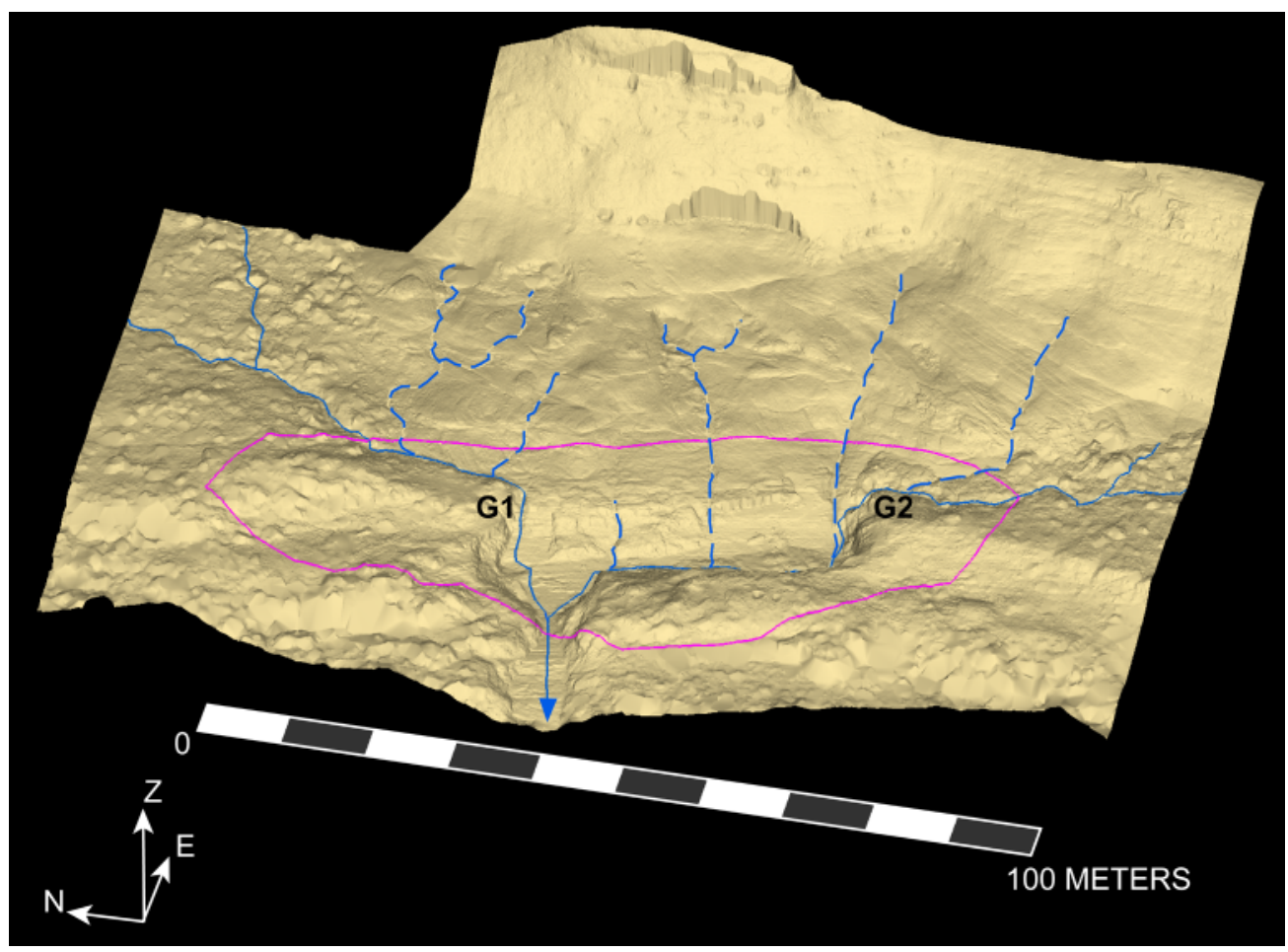

Figure 19. Site AZ:C:02:0075 (purple line)—Terrestrial lidar triangulated irregular network-based topographic surface map showing locations of gullies (blue lines). Gullies are cross-referenced with geomorphology data presented in table 10. 

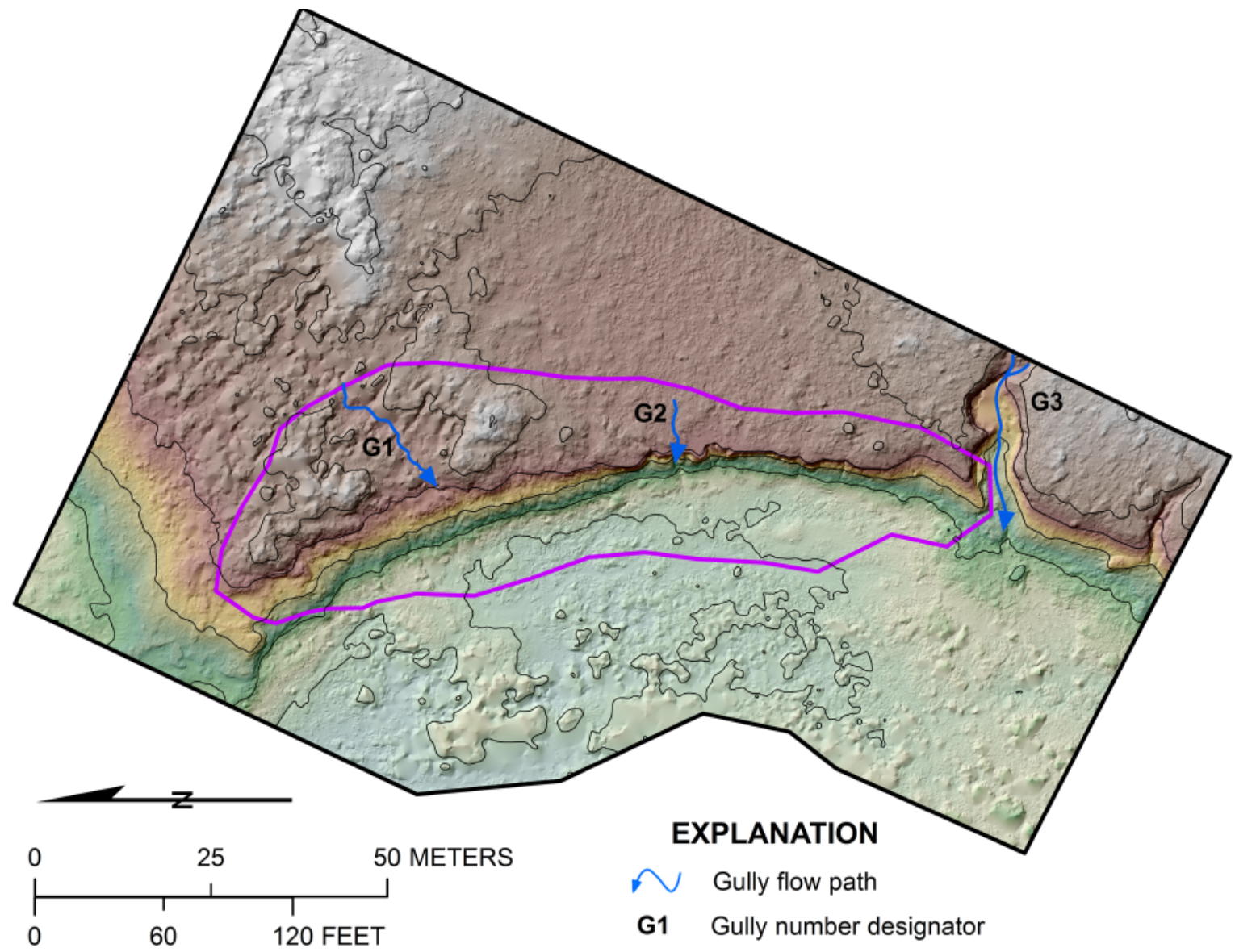

50 METERS

$\curvearrowleft$ Gully flow path

G1 Gully number designator

CONTOUR INTERVAL 1 METER

Archeological site boundary

Survey area boundary

Figure 20. Site AZ:C:02:0077—Terrestrial lidar $5 \mathrm{~cm}$ gridded topographic surface map with $1 \mathrm{~m}$ contours and gully locations. Gullies are cross-referenced with geomorphology data presented in table 11.

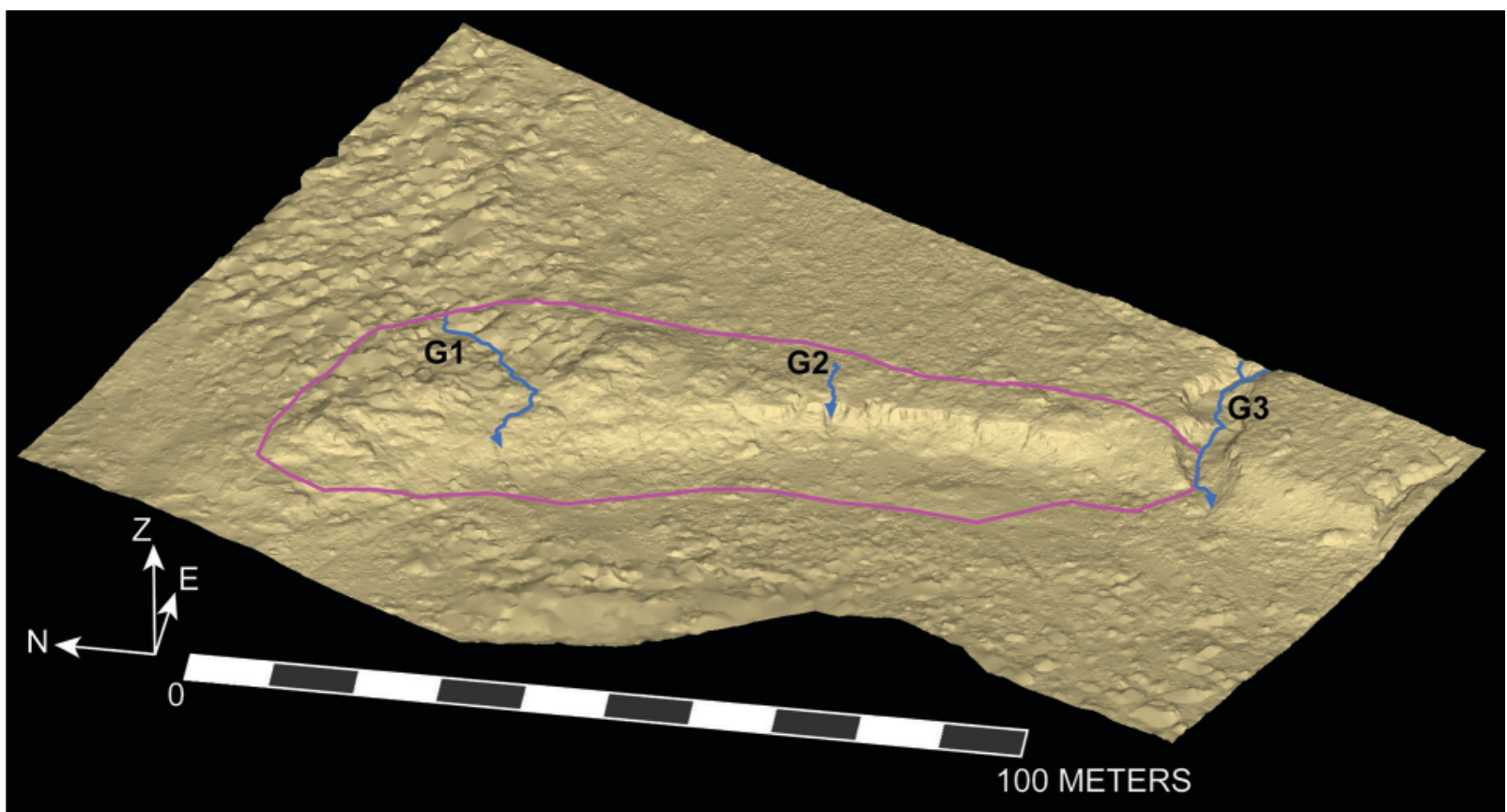

Figure 21. Site AZ:C:02:0077 (purple line)—Terrestrial lidar triangulated irregular network-based topographic surface map showing locations of gullies (blue lines). Gullies are cross-referenced with geomorphology data presented in table 11. 


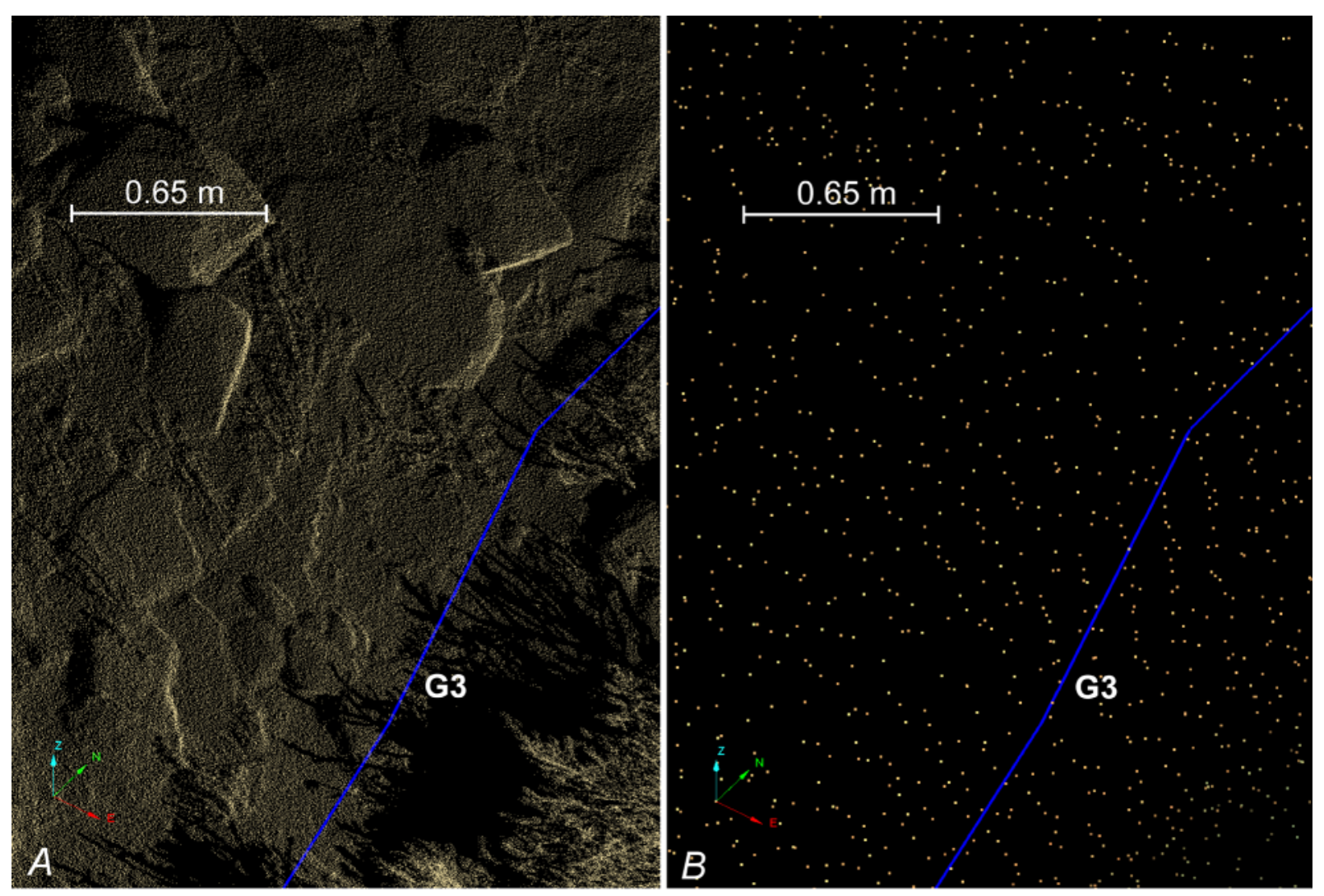

Figure 22. Point-cloud data of vegetation (lower right corner) and boulders (upper left corner) at site AZ:C:02:0032 (see fig. 15) using $(A)$ terrestrial lidar data with $\sim 1 \mathrm{~cm}$ point to point spacing, and $(B)$ airborne lidar data with $\sim 15 \mathrm{~cm}$ point to point spacing. Scale and perspective are identical in both images. Features are not identifiable in $(B)$ due to the lower point density compared with $(A)$.
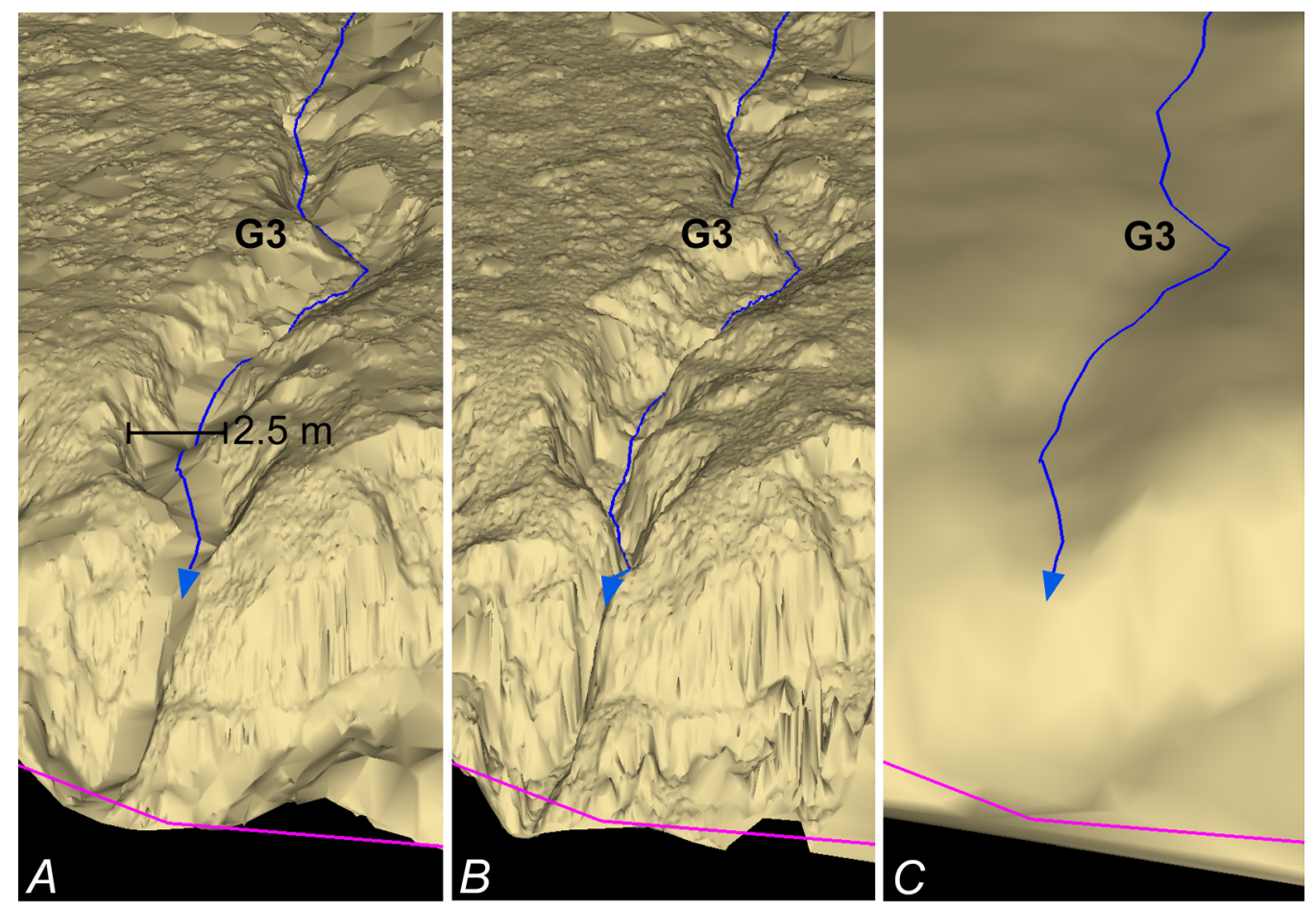

Figure 23. Surface resolution comparison at site AZ:C:02:0032, gully G3 (see fig. 15), among $(A)$ terrestrial lidar data, $(B)$ airborne lidar data and $(C)$ airborne photogrammetric digital surface model data. Resolution is similar between $(A)$ and $(B)$, with the exception of the gully bottom that the airborne lidar characterized in greater detail. Resolution in $(C)$ is less clear at this scale due to wider $(1 \mathrm{~m})$ point spacing in the digital surface model. 
Table 5. Area and point summary of terrestrial lidar data collection; m, meters.

\begin{tabular}{lcccc}
\hline Archeological site & $\begin{array}{c}\text { Plan area of site } \\
\text { boundary }\left(\mathbf{m}^{2}\right)\end{array}$ & $\begin{array}{c}\text { Approximate number of total } \\
\text { and (ground) terrestrial lidar } \\
\text { points within site boundary }\end{array}$ & $\begin{array}{c}\text { Terrestrial lidar ground } \\
\text { point fraction (percent) }\end{array}$ & $\begin{array}{c}\text { Terrestrial lidar ground } \\
\text { point density }\left(\mathbf{p o i n t s} / \mathbf{m}^{2}\right)\end{array}$ \\
\hline AZ:C:02:0032 & 4,700 & $7,187,000(5,042,000)$ & 70 & 1,100 \\
AZ:C:02:0035 & 2,700 & $11,552,000(8,679,000)$ & 75 & 3,200 \\
AZ:C:02:0075 & 2,200 & $19,312,000(13,786,000)$ & 71 & 6,300 \\
AZ:C:02:0077 & 2,600 & $7,010,000(2,343,000)$ & 33 & 900 \\
\hline
\end{tabular}

Table 6. Area and point summary of airborne lidar data collection; m, meters.

\begin{tabular}{lcccr}
\hline Archeological site & $\begin{array}{c}\text { Plan area of site } \\
\text { boundary }\left(\mathbf{m}^{2}\right)\end{array}$ & $\begin{array}{c}\text { Approximate number of total } \\
\text { and (ground) airborne lidar } \\
\text { points within site boundary }\end{array}$ & $\begin{array}{c}\text { Airborne lidar ground } \\
\text { point fraction (percent) }\end{array}$ & $\begin{array}{c}\text { Airborne lidar ground } \\
\text { point density (points/m²) }\end{array}$ \\
\hline AZ:C:02:0032 & 4,700 & $639,000(558,000)$ & 87 & 120 \\
AZ:C:02:0035 & 2,700 & $164,000(136,000)$ & 83 & 50 \\
AZ:C:02:0075 & 2,200 & $306,000(280,000)$ & 92 & 65 \\
AZ:C:02:0077 & 2,600 & $296,000(193,000)$ & & 70 \\
\hline
\end{tabular}

generally not noticeable, and in some cases the morphology of gully bottoms is captured in better detail compared to the terrestrial data. This is particularly true in steep, incised areas where the terrestrial lidar unit was not specifically aligned to collect the gully morphology (for example, compare the larger sizes of the TIN triangles in fig. $23 \mathrm{~A}$ generated from the terrestrial data to those in fig. $23 B$ generated from the airborne data). Overall point density is much more uniform compared to the terrestrial lidar data, and even in areas of dense vegetation, high-resolution bare-earth models can be constructed consistently. Visual recognition of features such as boulders and vegetation in the three-dimensional point-cloud data can generally be performed when their shortest dimension is at least $75 \mathrm{~cm}$, although positive identification is not always achievable even at this dimension (see for example, fig. 22B).

\section{Airborne Photogrammetric DSM Data}

Airborne photogrammetric DSM topographic data at each archeological site consist of 2,000-5,000 pixels per site. The $1 \mathrm{~m}$ pixel resolution of the DSM data is analogous to a lidar collection with point density of 1 point $/ \mathrm{m}^{2}$ and $1 \mathrm{~m}$ point spacing. The vegetation removal and pixel replacement procedure (see Methods section) resulted in more visually smooth, interpolated ground surfaces beneath mapped vegetated canopies. Due to the raster (that is, non-three-dimensional) visual representation of the DSM data, a comparable assessment of feature recognition capability is not possible within the context in which we analyzed the lidar datasets (for example, see fig $23 C$ for delineation of a gully using the DSM data). When analyzed in two dimensions, objects must typically be at least several times the size of the raster pixel resolution to be recognizable. For example, Leckie and others (2003) characterized $1.5 \mathrm{~m}$ diameter tree crowns using $60 \mathrm{~cm}$ pixel airborne imagery. Thus, our $1 \mathrm{~m}$ resolution data likely can be used for identifying objects at least $3 \mathrm{~m}$ (that is, several pixels) in length.

The more significant utility of DSM data is in performing landscape-scale geomorphological characterization, including watershed flow routing. Whereas these same routines can be performed using lidar data, photogrammetric DSMs are typically collected over much larger areas (the data presented herein being part of a larger canyon-wide $450 \mathrm{~km}$ long data set; Davis, 2012), thereby setting a much larger scale for regional analysis. Given our interest in identifying gullies using remotely sensed data, we evaluated the ability of the DSM data to automatically identify gully thalwegs (a thalweg is a line following the lowest points of a valley) using topographic modeling methods relative to conventional total station field surveying methods at three of the archeological sites (AZ:C:02:0032, AZ:C:02:0035, AZ:C:02:0075). We combined overland flow accumulation (ArcHydro Tools in ArcGIS v. 10.1, http://www.esri.com/; Greenlee, 1987; Jenson and Domingue, 1988; Tarboton and others, 1991) with plan convexity and roughness analyses (IDL programing language routine "TOPO DOIT" in ENVI v. 4.8 software, $h t t p: / / w w w$. exelisvis.com/) in a geographic information system (GIS) to objectively delineate gullies previously identified during field site visits (see Sankey and Draut, 2014). Our results (fig. 24) indicate that the DSM data can identify portions of gullies, but they are of limited utility for identifying the entire thalweg; in particular, shallow and narrow sections of gullies were not detectable due to the $1 \mathrm{~m}$ resolution of the data. The percentage of gully length identification (compared to the field survey data) was higher ( 90 percent) for areas with more deeply incised gullies (AZ:C:02:0075) compared to those with shallower gully cross-sections (AZ:C:02:0032; 40 percent), highlighting both the utility and limitation of DSM data for performing this type of analysis. 

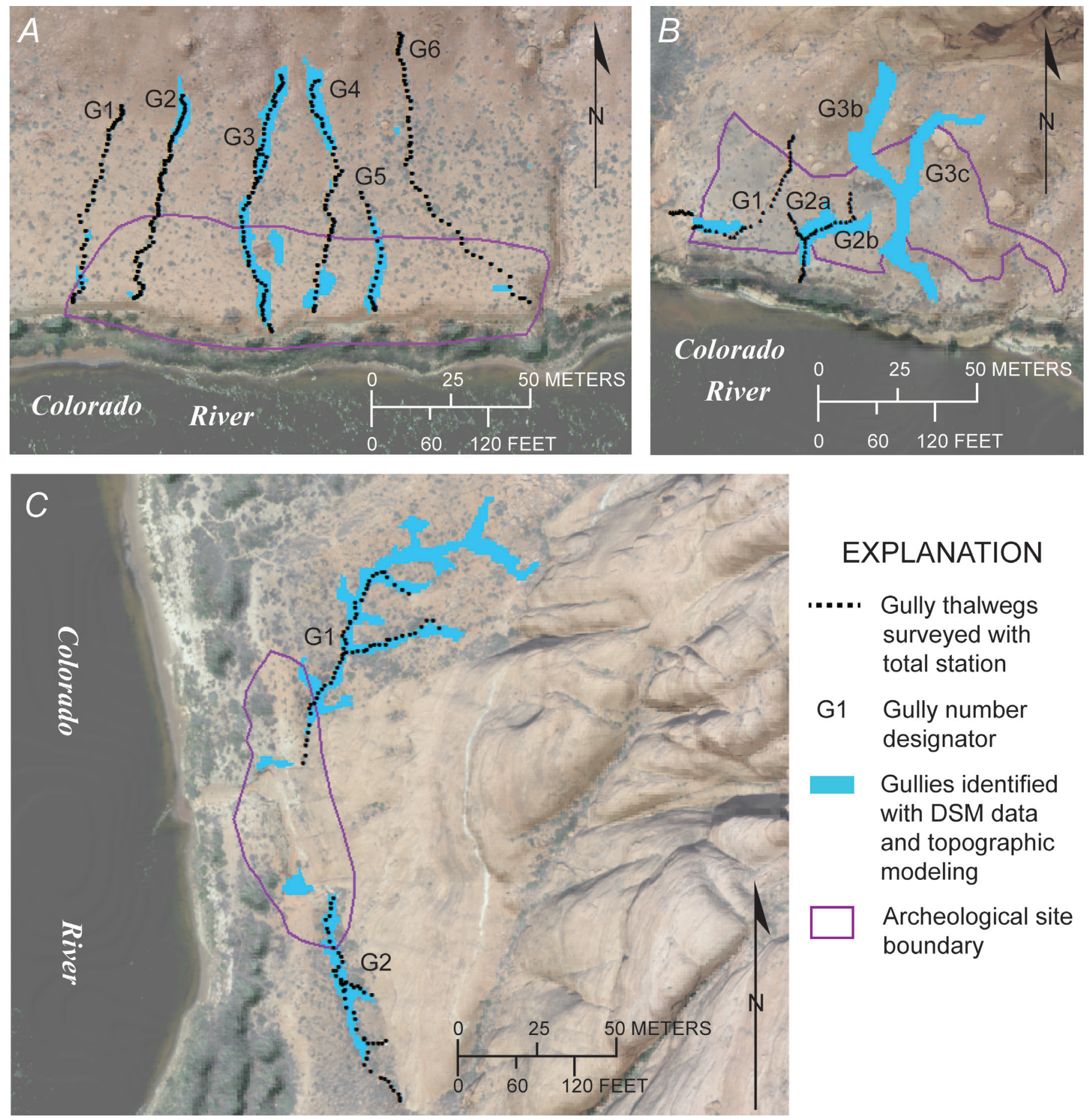

\section{EXPLANATION}

Gully thalwegs surveyed with total station

G1 Gully number designator

Gullies identified with DSM data and topographic modeling

Archeological site boundary

Figure 24. Results of objective gully delineation using airborne photogrammetric digital surface model data and topographic modeling at sites $(A)$ AZ:C:02:0032, $(B)$ AZ:C:02:0035 and $(C)$ AZ:C:02:0075. Thalweg lengths were positively identified for 40-, 50-, and 90-percent of the total station surveyed length for the three sites, respectively. Increasing positively identified percentages reflect an increase in overall terrain slope at the sites; shallow gullies at flatter sites were not easily detected. Base map is composed of the digital surface model-derived hillshade overlain with imagery. 


\section{Topographic Analysis}

Here we present detailed analyses comparing the relative accuracy, point density, and identifiable features within the terrestrial lidar, airborne lidar, and airborne photogrammetric DSM data sets. These analyses delineate the utility of the data sets for performing change detection and geomorphological analysis. Many of the ensuing topographic and geomorphological analyses are focused on the number, position, and morphology of gullies that traverse each archeological site. Existence of site gullies for these analyses was based on direct field observations and total station surveying at each site prior to the lidar and digital photogrammetry data analysis efforts. Thus, the number and position of the site gullies was known beforehand, thereby providing a baseline for data set comparison.

\section{Accuracy Comparison and Error Analysis}

A topographic data set is only as accurate as its potential error sources allow. Measurements made internal to a single data set (for example, the distance between two points surveyed within a single terrestrial lidar scan) will reflect only those terms related to the data collection method itself (that is, in this study, only the laser error, $E_{\text {laser }}$; equation 1). However, the accuracy of a more complex data set, such as a georeferenced surface model, will depend on both the internal errors, as well as those integrated as a result of positioning the data into georeferenced coordinate space. Thus, careful consideration must be given to the various error components when making measurements with topographic data.

The error assessments presented in the Methods section of this report provide detailed information on the error terms of each data set, as well as an indication of the total absolute error computed deterministically (that is, with all errors accounted for without implementing stochastic [random] terms) as conservative upper bounds (for example, calculated using the upper limit error from manufacturer specifications). The absolute error is considered that which might exist when comparing the data set to other data collected using entirely different methods. Here, we perform empirical error analyses as a check on these deterministic error estimates by directly comparing the point precision between the data sets (for example, between terrestrial and airborne lidar).

Our empirical error analysis focused on vertical comparisons $(\Delta \mathrm{Z})$ between data sets, calculated at the center of each of the eight survey panel targets (see Total Station Surveys of Panel Locations section). The results (table 7) indicate a very good correspondence (average $\Delta \mathrm{Z}=3.5 \mathrm{~cm}$ ) between terrestrial lidar and total station methods-a reflection of the use of identical methods (total station surveying) and survey control benchmarks to georeference each of these data sets. Comparison of this empirical error estimate to that from a deterministic analysis $(4.5 \mathrm{~cm}$, computed by adding $2.6 \mathrm{~cm}$ and $1.9 \mathrm{~cm}$ for the total relative vertical error in terrestrial lidar and total station data sets respectively, see table 2) indicates that the terrestrial lidar data are well within the expected deterministic error bounds. Note that an absolute error estimate comparison cannot be performed for these data because they are both referenced to identical benchmarks within the canyon. We therefore expect that change detection analyses between subsequent terrestrial lidar and (or) total station surveys can be accomplished at the 3-4 cm vertical threshold level, comparable to that performed in similar previous investigations in Grand Canyon National Park (Collins and others, 2012).

The results also indicate a very good correspondence (average $\Delta \mathrm{Z}=6.0 \mathrm{~cm}$ ) between the airborne lidar and total station data, and also a very good correspondence between the airborne and terrestrial lidar data (average $\Delta \mathrm{Z}=2.5 \mathrm{~cm}$ ), despite the use of different georeferencing methods (differential GPS for the airborne data versus total station for terrestrial lidar). Airborne lidar to terrestrial lidar comparisons are better for survey panels $\mathrm{P} 1$ through $\mathrm{P} 4$ (average $\Delta \mathrm{Z}=0.9 \mathrm{~cm}$ ) due to more tightly constrained positional data on the benchmarks used for total station surveying at the AZ:C:02:75 and AZ:C:02:0077 sites (K. Kohl, USGS, oral commun.). These results compare well with the error estimates calculated deterministically for the total absolute errors (that is, $16.1 \mathrm{~cm}$, calculated by adding 11.1 and $5.0 \mathrm{~cm}$ for the total absolute error between terrestrial lidar and airborne lidar respectively, see tables 2 and 3 ). Similar to the terrestrial lidar data, we expect that subsequent change detection analyses (for example, between a future terrestrial lidar data set and the airborne lidar data) can be performed at approximately the 3-4 cm vertical threshold level.

Empirically-derived errors between the airborne DSM data and other methods are much higher (for example, the average $\Delta \mathrm{Z}$ is $21.7 \mathrm{~cm}$ between the airborne DSM and total station data) in relation to those between terrestrial lidar and airborne lidar. This reflects the methodology required to georeference the entire canyon-wide airborne DSM data set (Davis, 2012; P. Davis, USGS, written commun., 2013). Still, the average absolute empirical vertical error is less than that calculated deterministically $(31 \mathrm{~cm}$, see table 4$)$ and the canyon-wide extent and accuracy of the data is exceptional for static-temporal analysis. However, change detection analyses performed using the photogrammetric DSM data are only recommended for capturing larger (several decimeter) scale vertical changes.

\section{Point Density Evaluation and Feature Recognition}

We investigated point density differences between the data sets by conducting focused assessments within each archeological site. Overall, the point density of the terrestrial lidar is much higher than that of the airborne lidar (tables 5 and 6), and both lidar data sets have significantly higher point density compared to that of the DSM data. These results are not surprising given the range and specifications of the data collection efforts. For example, by definition, the $1 \mathrm{~m}$ DSM data has a maximum point density of 1 point $/ \mathrm{m}^{2}$, and the airborne lidar data were 
Table 7. Vertical accuracy comparison of survey panel center elevations using different methods.

$[\Delta \mathrm{Z}$, vertical comparison between datasets. All values in centimeters]

\begin{tabular}{|c|c|c|c|c|c|c|c|}
\hline Survey panel & $\begin{array}{l}\text { Archeological } \\
\text { site }\end{array}$ & $\begin{array}{l}\text { Terrestrial } \\
\text { lidar-total } \\
\text { station } \Delta Z\end{array}$ & $\begin{array}{c}\text { Airborne } \\
\text { lidar-total } \\
\text { station } \Delta Z\end{array}$ & $\begin{array}{l}\text { Airborne } \\
\text { DSM-total } \\
\text { station } \Delta Z\end{array}$ & $\begin{array}{l}\text { Airborne } \\
\text { lidar-terrestrial } \\
\quad \text { lidar } \Delta Z\end{array}$ & $\begin{array}{c}\text { Airborne } \\
\text { DSM-terrestrial } \\
\quad \text { lidar } \Delta Z\end{array}$ & $\begin{array}{c}\text { Airborne } \\
\text { DSM-airborne } \\
\text { lidar } \Delta Z\end{array}$ \\
\hline P1 & AZ:C:02:0075 & 4.1 & 4.9 & 38.7 & 0.8 & 34.6 & 33.8 \\
\hline P2 & AZ:C:02:0075 & 3.7 & 4.6 & 29.4 & 0.9 & 25.7 & 24.8 \\
\hline P3 & AZ:C:02:0077 & 7.5 & 8.5 & 25.1 & 1.0 & 17.6 & 16.6 \\
\hline $\mathrm{P} 4$ & AZ:C:02:0077 & 2.7 & 3.7 & 24.0 & 1.0 & 21.3 & 20.3 \\
\hline P6 & AZ:C:02:0035 & 3.0 & 7.2 & 19.3 & 4.2 & 16.3 & 12.1 \\
\hline P7 & AZ:C:02:0032 & 1.3 & 5.2 & 15.9 & 3.9 & 14.6 & 10.7 \\
\hline \multirow[t]{2}{*}{ P8 } & AZ:C:02:0032 & 3.0 & 7.3 & 19.4 & 4.3 & 16.4 & 12.1 \\
\hline & Average & 3.5 & 6.0 & 21.7 & 2.5 & 18.2 & 15.7 \\
\hline
\end{tabular}

collected under a specification of

50 points $/ \mathrm{m}^{2}$ per flight line at a larger range $(200 \mathrm{~m})$ compared to the terrestrial lidar data $(40 \mathrm{~m})$. Still, as these specifications can be considered to be at the high-end of resolution for current (2009-14) state-of-the-art practices, they highlight what can be analyzed with respect to geomorphological characterization and topographic change detection using these methods.

As identified in the results, the terrestrial lidar data are capable of resolving features as small as $15 \mathrm{~cm}$ (in the shorter-dimension). For archeological site geomorphology, this resolution is useful for discerning shallow gully width and depths, small rock movements, and the presence of short, narrow-crowned vegetation (for example, prickly pear cacti). With an approximate feature recognition scale of $75 \mathrm{~cm}$, the airborne lidar can be used to visually identify larger features such as well-developed gully systems, talus boulders, and shrubs. The DSM data have similar limitations, with a feature recognition size of several meters that can only provide positive identification of large gullies, shrubs, and boulders. However, whereas terrestrial lidar excels in small-scale feature identification, airborne lidar and DSM methods excel in regional-scale characterization and collect more consistent point (pixel) densities within each site due to their respective downward-looking view angles. This minimizes the low point density anomalies that are created by side-looking terrestrial lidar shadows, which may, in some cases, miss important but concealed ground points.

Our gully identification analyses using the photogrammetric DSMs highlighted the utility and limitations of automatic, digital gully-thalweg detection with remotely sensed data. As expected, the gully-width detection limit was determined to be at the same resolution as the data. Thus, we would expect similar results (that is, gully-width detection limits of $\sim 1-5 \mathrm{~cm}$ and $10-15 \mathrm{~cm}$ for the terrestrial and airborne lidar, respectively). However, exploratory analyses performed during this study with flow routing through a $5 \mathrm{~cm}$ grid created using the terrestrial lidar data often identified an overly complex and unrealistic representation of true gully positions, especially in flat terrain. Thus, an efficiency analysis aimed at identifying the feature scale of interest is suggested before selecting a single data type for large-scale analyses. Based on our results and understanding of geomorphology of the sites investigated herein, a sufficiently detailed watershed routing scale is likely on the order of $10-50 \mathrm{~cm}$ resolution for identifying positions and widths of both shallow and (or) incised gullies.

\section{Geomorphological Analysis}

The combined terrestrial-airborne lidar data and airborne photogrammetric DSMs provide the unprecedented ability to perform detailed geomorphological analysis of archeological sites in Glen Canyon. These, in turn, can inform expected future responses of the sites from active fluvial, alluvial, and aeolian processes. Whereas most geomorphological attributes (for example, surface slope, gully width, gully spacing) are well-displayed in the airborne data, attributes on the terrace edge and scarp are only captured in detail by terrestrial data with more perpendicular incident angles to the topography. The DSM data are particularly useful for describing the greater landscape context in the area around and between sites, especially the overall relief from the contemporary river channel to the archeological sites, and from the sites to the canyon rim. Here, we present detailed geomorphological analyses of each of the four sites using the combined data sets. We report on general and specific topographic attributes, including the spatial distribution and incision depth of site-traversing gullies that have the potential to erode archeological resources.

\section{Site AZ:C:02:0032 Geomorphology}

Site AZ:C:02:0032 sits $\sim 11 \mathrm{~m}$ above the river surface (at $227 \mathrm{~m}^{3} / \mathrm{s}$ [8,000 ft $\left.\mathrm{ft}^{3} \mathrm{~s}\right]$ Colorado River discharge) and 250 $\mathrm{m}$ below the edge of the canyon rim, on a fluvial terrace that dips $7^{\circ}$ to the south. The terrace has been the subject of several geoarchaeology investigations (Leap and Neal, 1992; 
Anderson, 2006; Pederson and others, 2011) that have shown the terrace formed through a complex history of cut-and-fill sequences extending over several thousand years. Immediately cliffward (north) of the site, alluvial fans dipping $11^{\circ}$ drain rock fall talus slopes as much as $42 \mathrm{~m}$ tall. The talus slopes abut the base of near-vertical bedrock cliffs and the slopes appear to be at, or near, the angle of repose, dipping $26^{\circ}$ towards the river.

The site is traversed by six gullies with varying degree of incision (table 8). Only two gullies (G3 and G5) have cut significantly into the terrace to depths $>40 \mathrm{~cm}$. The other gullies are relatively shallow and, in some cases, a distinct and continuous gully thalweg is difficult to discern even with on-site observations. Herein, we identify these types of gullies as "shallow/ ephemeral", and distinguish them from those that are incised and generally termed "classical" gullies (Kirkby and Bracken, 2009). All gullies, with the exception of G5, begin in the talus. These five gullies are nearly equally-spaced $\sim 20-30 \mathrm{~m}$ apart, as measured orthogonally to their flow path on the terrace. Whereas exact measurements of gully drainage basins (catchment areas) are difficult to discern in this landscape due to the complex nearvertical topography of the adjacent cliffs, the regularity of gully spacing suggests that drainage basins may be nearly equal in size (Horton, 1945; Perron and others, 2008). However, the deeper incision of gullies G3 and G5 suggest that these gullies experience greater overland flow input. Gully G3 begins near the apex of the talus and likely has a greater overland flow accumulation area. Further, it may also receive spillover input from higher up on, or at the top of, the 250-m-tall cliff walls. Gully G5 does not begin in the talus, but rather within the alluvial fan deposits just north of the site boundary. The greater incision depth at G5 and close lateral proximity to the deeply-incised talus section of gully G4 suggests that G5 is the detached, former gully channel for the current G4 drainage. Gully G5 likely became inactive after a debris flow originating on the talus slope deposited its sediment load on the upper terrace, filling in the gully channel and diverting future flows to the west (figs. 14 and 15). This allowed gully G4 to become established. This sequence of events suggests that the incision rate should decrease for G5, but that it might increase for $\mathrm{G} 4$, now that it captures the majority of the upstream drainage in this area of the site. Assuming regularity of incision-causing overland flow events, the significantly deeper incision in G5 compared to G4 indicates that gully G4 likely has been present for less time compared to the period when G5 was the main drainage gully here. This has important implications for future archeological site monitoring with respect to where erosion should and should not be expected.

The gullies cross the edge of the terrace with different degrees of incision. Whereas knickpoints into the edge can be distinguished for each gully, in some cases, the exact location of an active channel is not always clear due to subsurface piping as the gullies approach the near-vertical terrace edge. Herein, we differentiate gully incision measured at the edge of the terrace, from terrace erosion that occurs due to processes other than up-watershed channelized overland flow (for example, sloughing and tensile failure of the terrace face). Whereas the larger, more incised gullies (G3 and G5) should have the largest terrace-edge incision, this is only true for G3 (table 8). Gully G2, which is relatively shallow and subtle over the width of the terrace, has the most edge incision, and gully G4 is more deeply incised than its predecessor G5. This indicates that nonhomogeneous retreat of the terrace edge may be resetting the overland flow incision rate at particular sections of the terrace (for example, Flint, 1982). Terrace erosion and cutbank retreat have been observed in the vicinity of this site, as well as at site AZ:C:02:0035, between 1956 and 2000 (Burchett, 1996; Grams and others, 2007). Any additional terrace-edge slumping would continue to compromise the integrity of these sites, thereby indicating that processes in addition to gully incision should be investigated as potential threats to cultural sites here.

\section{Site AZ:C:02:0035 Geomorphology}

Site AZ:C:02:0035 is located $\sim 18 \mathrm{~m}$ above the river surface (at $227 \mathrm{~m}^{3} / \mathrm{s}$ [8,000 ft $3 / \mathrm{s}$ Colorado River discharge) and

Table 8. Summary of gully topography at site AZ:C:02:0032; m, meters.

\begin{tabular}{|c|c|c|c|c|c|}
\hline Site and gully ID & General description & $\begin{array}{c}\text { Approximate } \\
\text { maximum width }^{1}(\mathrm{~m})\end{array}$ & $\begin{array}{c}\text { Approximate } \\
\text { maximum depth }^{1}(\mathrm{~m})\end{array}$ & $\begin{array}{l}\text { Location of gully } \\
\text { head }\end{array}$ & $\begin{array}{l}\text { Approximate gully } \\
\text { incision depth at } \\
\text { terrace edge }{ }^{2}(\mathrm{~m})\end{array}$ \\
\hline AZ:C:02:0032-G1 & shallow/ephemeral & $\mathrm{n} / \mathrm{a}$ & $\mathrm{n} / \mathrm{a}$ & mid-talus & 1.1 \\
\hline AZ:C:02:0032-G2 & shallow/ephemeral & $\mathrm{n} / \mathrm{a}$ & $\mathrm{n} / \mathrm{a}$ & mid-talus & 5.2 \\
\hline AZ:C:02:0032-G3 & $\begin{array}{l}\text { incised with vertical } \\
\text { banks }\end{array}$ & 1.60 & 0.60 & top of talus & 4.8 \\
\hline AZ:C:02:0032-G5 & $\begin{array}{l}\text { incised with sloping } \\
\text { banks }\end{array}$ & 2.00 & 0.40 & alluvial fan & 3.1 \\
\hline$A Z: C: 02: 0032-G 6$ & shallow/ephemeral & $\mathrm{n} / \mathrm{a}$ & $\mathrm{n} / \mathrm{a}$ & top of talus & 3.6 \\
\hline
\end{tabular}

${ }^{1}$ Gully dimensions (with $\pm 5 \mathrm{~cm}$ accuracy) are measured only within the site boundary. " $\mathrm{n} / \mathrm{a}$ " indicates gully is not incised or channelized within the site boundary with the exception at the terrace edge.

${ }^{2}$ Gully incision at terrace edge (with $\pm 10 \mathrm{~cm}$ accuracy) is defined as the elevation difference from the terrace surface to the point where each gully drains over a vertical edge greater than $2 \mathrm{~m}$ in height. 
$250 \mathrm{~m}$ below the edge of the canyon rim on a fluvial terrace that dips $8^{\circ}$ to the south-southwest. In addition to encompassing the majority of the fluvial terrace, the archeological site is located on some of the adjacent upslope alluvial fan and talus slopes. These, in turn, abut vertical to sub-vertical bedrock cliffs that top out at the canyon rim. The alluvial fans transition gradually upward from the fluvial terrace into adjacent debris lobes and the toes of the talus slopes. The talus slopes here are somewhat steeper (in many cases reaching $32^{\circ}$ ) than those adjacent and upstream at site AZ:C:02:0032; this may be due to the presence of very large diameter $(>4 \mathrm{~m})$ boulders that are buried within the talus at AZ:C:02:0035 and effectively steepen the angle of repose.

The site is traversed by four gullies with different degrees of incision (table 9). Two gullies (G3 and G4) are deeply incised $(>2 \mathrm{~m})$ and initiate high up the talus slopes to the north of the site. This suggests that precipitation spillover inputs from the adjacent cliffs by Hortonian overland flow (when rainfall exceeds the infiltration capacity of the basin, a prime cause of soil erosion; for example, see Selby, 1985) is responsible for the initiation of the well-dissected topography of the gullies across the slopes. Gully G1 also initiates on the talus slopes, but only begins midway between the terrace and top of the talus. The significantly lower incision depth of this gully may be indicative of a smaller overland flow accumulation area, although its deep incision across the terrace edge, along with evidence for avulsion between two spillover points, signifies that high energy flow and aggradation must sometimes occur (Schumm, 1977). The incision depth at the terrace edge might also be related to the greater relief of the site relative to the main stem river surface $\left(\sim 18 \mathrm{~m}\right.$ at $227 \mathrm{~m}^{3} / \mathrm{s}\left[8,000 \mathrm{ft}^{3} / \mathrm{s}\right]$ Colorado River discharge) when compared to the other investigated sites. Gully G2 is anomalous in that it initiates on alluvial fan/ slope-wash sediments within the site boundary (as opposed to the talus slopes out of the site boundary), but is incised deeply near the terrace edge (table 9). We suggest that because the alluvial fan in which the gully initiates is both steeper $\left(13^{\circ}\right)$ than the surrounding terrace $\left(7^{\circ}\right)$ and has aggraded well outwards across the terrace, incision at the terrace edge has been more efficient than would have otherwise occurred if the gully traversed only the flatter terrace for a longer distance.
Gully incision at the terrace edge scales with maximum gully depth at this site (table 9); the most deeply eroded gullies have incised through the terrace edge by the largest degree. At this site we do not see the resetting of the terrace-edge incision rates that fluvial-induced bank collapse appears to have caused upstream at site AZ:C:02:0032. Rather, the terrace edge here is now protected from most main stem Colorado River flows by a 3-m-tall sandstone cliff that outcrops at the terrace toe across the entire site. This configuration has likely resulted from the 1965 post-dam pulsed high flow erosion of the deposits that previously overlaid the rock outcrops (Grams and others, 2007). In their now-eroded configuration, terraces containing archeological sites that are located on bedrock platforms of height greater than maximum river elevation induced changes from dam operations may be more protected from future direct fluvialinduced erosion than terraces lacking such bedrock platforms.

\section{Site AZ:C:02:0075 Geomorphology}

Site AZ:C:02:0075 is located $\sim 8 \mathrm{~m}$ above the river surface (at $227 \mathrm{~m}^{3} / \mathrm{s}$ [8,000 $\left.\mathrm{ft}^{3} / \mathrm{s}\right]$ Colorado River discharge) and $280 \mathrm{~m}$ below the edge of the canyon rim on a heavily-dissected fluvial terrace that abuts an eroded, low-angle $\left(<10^{\circ}\right)$ bedrock platform. To the east of the site and $\sim 8 \mathrm{~m}$ higher in elevation, the bedrock platform transforms to rounded cliffs up to $100 \mathrm{~m}$ tall and then to near-vertical cliffs. The fluvial terrace is narrow $(\sim 20 \mathrm{~m})$ at the site, gradually widening both upstream and downstream. Approximately $35 \mathrm{~m}$ in the upstream direction (and moving towards neighboring site AZ:C:02:0077), the terrace becomes multi-layered with three distinct 3-m-high terrace scarps. However, only two of the terraces can be delineated easily at this site (AZ:C:02:0075) because the lowest terrace blends into a low-angle bedrock platform just outside the site boundary at the river's edge.

The site is traversed by two gullies (table 10) that initiate along the bedrock-terrace interface to the north and south of the site, and are fed by numerous (more than five) bedrock-sourced tributary channels that traverse the low-angle bedrock platform. The northern gully (G1) has two branches that merge $18 \mathrm{~m}$ upstream of the site boundary; both branches are incised into the terrace throughout their length. The merged gully channel

Table 9. Summary of gully topography at site AZ:C:02:0035; m, meters.

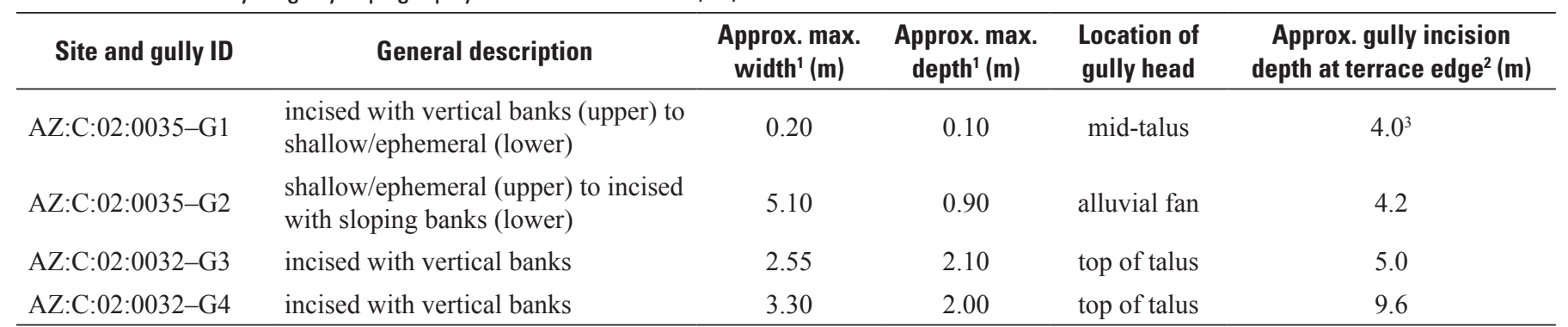

${ }^{1}$ Gully dimensions (with $\pm 5 \mathrm{~cm}$ accuracy) are measured only within the site boundary.

${ }^{2}$ Gully incision at terrace edge (with $\pm 10 \mathrm{~cm}$ accuracy) is defined as the elevation difference from the terrace surface to the point where each gully drains over a vertical edge greater than $2 \mathrm{~m}$ in height.

${ }^{3}$ Gully ends in a tributary channel and is fully incised to the tributary. 
becomes more incised and gradually cuts to bedrock within the site boundary before merging with the terminus of the southern gully (G2). Gully G2 begins at the base of a talus slope adjacent to the more vertical cliff sections to the south of the site and is joined along its length by several branches that begin as shallow bedrock drainages (fig. 7-dashed lines). As the main gully enters the site boundary, it becomes more incised with its east (cliffside) bank bounded by bedrock and its west (riverside) bank bounded by the remnants of a fluvial terrace. The gully widens and eventually reaches incision depths as great as $2.5 \mathrm{~m}$ before entering an even more deeply incised area between the bedrock and the remaining terrace. Here, the channel has formed a roughly rectangular and flat-floored, $46 \mathrm{~m}$ long, $12 \mathrm{~m}$ wide, and $3 \mathrm{~m}$ deep "basin." Gully G1 enters into the basin at its north end, and after merging with Gully 2, turns $90^{\circ}$ towards the river, discharging over a first flat, and then low-angled, stair-stepped bedrock platform that borders the river's edge. We interpret the eroded basin to be related to the large watershed area that drains to G2, and which includes a large quantity of low-permeability bedrock substrate. Much of the length of the basin abuts bedrock such that high-energy overland flow has likely exacerbated gully incision and widening here. In addition, it appears that the high flows of 1983, that peaked at around 2,755 $\mathrm{m}^{3} / \mathrm{s}\left(97,300 \mathrm{ft}^{3} / \mathrm{s}\right)$ (Schmidt and Grams, 2011b), would have backed up into the gully, pooling on the bedrock floor and saturating the base of adjoining fluvial deposits. This event may have also contributed to the widening of the gully. Archeological sites such as this, that are within or adjacent to sloping bedrock platforms, should thus be expected to undergo higher degrees of erosion compared to those founded entirely on fluvial and alluvial deposits.

\section{Site AZ:C:02:0077 Geomorphology}

Site AZ:C:02:0077 is located $\sim 10 \mathrm{~m}$ above the river surface (at $227 \mathrm{~m}^{3} / \mathrm{s}$ [8,000 $\mathrm{ft}^{3} / \mathrm{s}$ ] Colorado River discharge) and $280 \mathrm{~m}$ below the edge of the canyon rim on terraces formed by

both pre- and post-dam high-water levels of the Colorado River (Grams and others, 2007). The site occupies the upper two layers of the three, 3-m-high terrace escarpments found immediately downstream towards site AZ:C:02:0075. The highest terrace is hummocky but essentially flat to the east of the site, sloping at $<1^{\circ}$ away from the bordering cliffs. To the northeast of the site, the terrace is only slightly more inclined $\left(\sim 3^{\circ}\right.$ dipping to the southwest) due to alluvial aggradation of talus deposited out of an adjacent cliff alcove. The upper terrace is partly covered with aeolian dunes that are sometimes stabilized by shrubs and intermittent biological soil crust. The west part of the site is located on the lower of the two terrace treads and is generally flat. The 3-m-tall escarpment that separates the two terraces is sloping $\left(\sim 20^{\circ}\right)$ at the north end of the site and becomes vertical and highly dissected towards the south end of the site.

The site is traversed by two gullies and bounded on the south by a third (table 11). The two gullies that traverse the site originate as subtle swales in the terrace to the immediate east of the site, but neither is incised through the site. Only G2 shows signs of downcutting at the terrace edge, where a 1.3-m-deep gully has formed over a $2 \mathrm{~m}$ length. Below the terrace, the two gullies dissipate and become indistinguishable, most likely due to the presence of sandy surficial sediment with high infiltration capacity. The bounding gully to the south of the site (G3) initiates from two branches located at the outlet of two deep bedrock clefts in the adjacent cliffs. The branches join $\sim 25 \mathrm{~m}$ from the cliff outlets and form a deeply incised gully with up to 2.1-m-tall vertical banks along the remainder of its length. Beyond the terrace scarp, the gully is not incised, presumably due to the high infiltration capacity of the soils located on the lower terrace surface. Instead, this gully, along with the two to the north, dissipates on the lower terrace surface and cannot be traced over the course of the $\sim 100 \mathrm{~m}$ between the scarp and the river. The lack of terrace incision at G1 and G2 compared to that of a gully formed by bedrock cleft outlets (G3) suggests that on-site overland flow to G1 and G2 is either minimal or that surficial terrace substrates have high infiltration capacities and (or) resistance to erosion within the site.

\section{Conclusions}

The fate of many archeological sites in Glen Canyon National Recreational Area, as well as in other areas of the southwestern United States, will be determined by their geomorphological settings and the erosion that they undergo. For those sites located in or on fluvial- and alluvial-based terraces of the Colorado River below Glen Canyon Dam, they may also be subjected to modern anthropogenic effects of the currently regulated river. Detailed geomorphologic assessments

Table 10. Summary of gully topography at site AZ:C:02:0075; m, meters.

\begin{tabular}{cccccc}
\hline Site and gully ID & General description & $\begin{array}{c}\text { Approx. max. } \\
\text { width }^{\mathbf{1}}(\mathbf{m})\end{array}$ & $\begin{array}{c}\text { Approx. max. } \\
\text { depth }^{\mathbf{1}} \mathbf{( m )}\end{array}$ & $\begin{array}{c}\text { Location of gully } \\
\text { head }^{-}\end{array}$ & $\begin{array}{c}\text { Approx. gully incision depth } \\
\text { at terrace edge }^{2}(\mathbf{m})\end{array}$ \\
\hline AZ:C:02:0075-G1 & incised with sloping banks & 1.50 & 0.30 & terrace & $\mathrm{n} / \mathrm{a}$ \\
AZ:C:02:0075-G2 & incised with vertical banks & 1.50 & 2.50 & toe of talus & 5.0 \\
\hline
\end{tabular}

${ }^{1}$ Gully dimesions (with $\pm 5 \mathrm{~cm}$ accuracy) are measured only within the site boundary. For G2, dimensions do not include "basin" area near gully toe.

${ }^{2}$ Gully incision at terrace edge (with $\pm 10 \mathrm{~cm}$ accuracy) is defined as the elevation difference from the terrace surface to the point where each gully drains over a vertical edge greater than $2 \mathrm{~m}$ in height. " $\mathrm{n} / \mathrm{a}$ " indicates that the gully does not reach the river's edge. 
Table 11. Summary of gully topography at site AZ:C:02:0077; m, meters.

\begin{tabular}{|c|c|c|c|c|c|}
\hline Site and gully ID & General description & $\begin{array}{l}\text { Approx. maxi. } \\
\text { width }^{1}(\mathrm{~m})\end{array}$ & $\begin{array}{l}\text { Approx. max. } \\
\text { depth }^{1}(\mathrm{~m})\end{array}$ & $\begin{array}{l}\text { Location of } \\
\text { gully head }\end{array}$ & $\begin{array}{l}\text { Approx. gully incision depth at } \\
\text { terrace } \operatorname{edge}^{2}(\mathrm{~m})\end{array}$ \\
\hline $\mathrm{AZ}: \mathrm{C}: 02: 0077-\mathrm{G} 1$ & shallow/ephemeral & $\mathrm{n} / \mathrm{a}$ & $\mathrm{n} / \mathrm{a}$ & terrace & $\mathrm{n} / \mathrm{a}$ \\
\hline AZ:C:02:0077-G3 & incised with vertical banks & 7.20 & 2.20 & bedrock & 2.2 \\
\hline
\end{tabular}

${ }^{1}$ Gully dimensions (with $\pm 5 \mathrm{~cm}$ accuracy) are measured only within the site boundary. " $\mathrm{n} / \mathrm{a}$ " indicates gully is not incised or channelized within the site boundary with the exception at the terrace edge.

${ }^{2}$ Gully incision at the terrace edge (with $\pm 10 \mathrm{~cm}$ accuracy) is defined as the elevation difference from the terrace surface to the point where each gully drains over a vertical edge greater than $2 \mathrm{~m}$ in height. For this site, the vertical edge is the escarpment between the two upper terraces (i.e., not bordered by the current level of the Colorado River).

provide a means to determine what, if any, these effects may be, by linking erosion and depositional process histories to the current topographical setting of sites. We have shown that the use of high-resolution topographic surveying techniques, such as terrestrial and airborne lidar, and photogrammetric digital surface models, provide extensive and complementary information that can be used to make such assessments. We determined that each method has its own strengths and weaknesses, and that the terrestrial and airborne lidar were mostly interchangeable for many important topographic characterization and monitoring purposes. However, terrestrial lidar provides an enhanced capacity for feature recognition and gully morphology delineation at scales relevant for the more subtle changes that might be detected with short-term (that is, monthly to annual) monitoring, and that are most relevant for detecting changes at archaeological sites, where even shallow gullies have the potential to detrimentally affect cultural features and deposits. Airborne methods, whether by laser or optical sensors, are better suited for reach- and regional-scale topographic mapping and hydrologic modeling; for these types of analyses, stationary terrestrial lidar is not suitably efficient.

Comparative error analysis of the three methods demonstrates very good precision between, and accuracy of, the terrestrial and airborne lidar data, indicating the topographic elevation change detection at the several-centimeter scale is possible using these datasets. Thus, large-scale, baseline data collection with airborne lidar followed by site-specific periodic data collection with terrestrial lidar is likely to provide the most efficient methodology for regional-scale monitoring. Whereas the overall error of photogrammetric digital surface model data is an order of magnitude greater than for the lidar methods, the data accuracy is still sufficient for investigations of reach-scale variability of many geomorphological characteristics.

Our site-specific geomorphic analyses of four archeological sites in Glen Canyon indicate that their current topographical conditions are a result of different, and sometimes competing, erosional agents, including bedrock- and terrace-based overland flow, fluvial-induced terrace-bank collapse, and alluvial-fan-generated debris flows. Although the influences of anthropogenic-induced erosion from dam operations were not specifically analyzed in this report, we did identify geomorphic settings where effects are either more or less likely to affect archeological site stability. This information can be used to assist with future monitoring efforts of these sites and identification of similar conditions for other archeological sites along the Colorado River corridor in Glen Canyon. Overall, the high-resolution topography collected as a part of this investigation, along with the geomorphological investigation methodology used herein, provide the required basic data and methods necessary to begin identifying geomorphic evolution patterns related to the potential for short- and long-term effects of dam operations on archeological sites within Glen Canyon.

\section{References}

Adams, W.Y., Lindsay, A.J., and Turner, C.G., 1961, Survey and excavations in lower Glen Canyon, 1952-1958: Flagstaff, Ariz., Museum of Northern Arizona Bulletin, no. 36, series no. 3, 62 p. and appendices.

Anderson, K.C., 2006, Geoarcheological investigations of 53 sites between Glen Canyon Dam and Paria Riffle: Navajo Nation Archaeology Department Report No. 05-229, submitted to Bureau of Reclamation, Upper Colorado Region, Salt Lake City, Utah, report on file at Bureau of Reclamation.

Boehler, W., Vicent, M.B., and Marbs, A., 2003, Investigating laser scanner accuracy: Presented at the XIX International Committee for Documentation of Cultural Heritage (CIPA) Symposium, Antalya, Turkey, 2003, 9 p., accessed June 2, 2014, at http://www-group.slac.stanford.edu/met/align/ Laser_Scanner/laserscanner_accuracy.pdf.

Burchett, T.W., 1996, Glen Canyon Environmental Studies Fiscal Year 1996 Trip Report: Glen Canyon National Recreation Area, National Park Service, Page, Ariz., 43 p., accessed January 17, 2014, at http://www.riversimulator. org/Resources/GCMRC/GCES/Cultural/Burchett1996.pdf.

Collins, B.D., Brown, K.B., and Fairley, H.C., 2008, Evaluation of terrestrial LIDAR for monitoring geomorphic change at archeological sites in Grand Canyon National Park, Arizona: U.S. Geological Survey Open-File Report 2008-1384, 60 p., at http://pubs.usgs.gov/of/2008/1384/. 
Collins, B.D., Corbett, S.C., Fairley, H.C., Minasian, D., Kayen, R., Dealy, T.P., and Bedford, D.R., 2012, Topographic change detection at select archeological sites in Grand Canyon National Park, Arizona, 2007-2010: U.S. Geological Survey Scientific Investigations Report 20125133, 77 p., at http://pubs.usgs.gov/sir/2012/5133/.

Collins, B.D., and Kayen, R., 2006, Applicability of terrestrial LIDAR scanning for scientific studies in Grand Canyon National Park, Arizona: U.S. Geological Survey OpenFile Report 2006-1198, 27 p., at http://pubs.usgs.gov/ of/2006/1198/.

Collins, B.D., Minasian, D., and Kayen, R., 2009, Topographic change detection at select archeological sites in Grand Canyon National Park, Arizona, 2006-2007: U.S. Geological Survey Scientific Investigations Report 2009-5116, 58 p., at http://pubs.usgs.gov/sir/2009/5116/.

Crampton, C.G., 2009, Ghosts of Glen Canyon-History beneath Lake Powell (2d ed.): Springville, Utah, Bonneville Books, 176 p.

Davis, P.A., 2012, Airborne digital-image data for monitoring the Colorado River corridor below Glen Canyon Dam, Arizona, 2009-Image-mosaic production and comparison with 2002 and 2005 image mosaics: U.S. Geological Survey Open-File Report 2012-1139, at http://pubs.usgs.gov/ of/2012/1139/.

Doelle, W.H., ed., 2000, Final Report - Cultural Resource Program Assessment: Grand Canyon Monitoring and Research Center, Protocol Evaluation Panel, Flagstaff, Ariz., 53 p., accessed June 2, 2014, at http://www.gcmrc.gov/library/ reports/PEP/Doelle2000.pdf.

Draut, A.E., 2012, Effects of river regulation on aeolian landscapes, Colorado River, southwestern USA: Journal of Geophysical Research-Earth Surface, v. 117, no. F2, doi:10.1029/2011JF002329.

Draut, A.E., and Rubin, D.M., 2008, The role of aeolian sediment in the preservation of archeological sites along the Colorado River corridor Grand Canyon National Park, Arizona: U.S. Geological Survey Professional Paper 1756, 71 p., at http://pubs.usgs.gov/pp/1756.

Fairley, H.C., 2005, Cultural resources in the Colorado River corridor, in Gloss, S.P., Lovich, J.E., and Melis, T.S., eds., The state of the Colorado River ecosystem in Grand Canyon: U.S. Geological Survey Circular 1282, p. 177-192, at http://pubs.usgs.gov/circ/1282/.
Fairley, H.C., Bungart, P.W., Coder, C.M., Huffman, J., Samples, T.L., and Balsom, J.R., 1994, The Grand Canyon river corridor survey project-Archeological survey along the Colorado River between Glen Canyon Dam and Separation Canyon: Flagstaff, Ariz., Grand Canyon National Park, prepared in cooperation with the Bureau of Reclamation, Glen Canyon Environmental Studies, cooperative agreement no. 9AA-40-07920.

Fairley, H.C., and Sondossi, H., 2010, Applying an ecosystem framework to evaluate archaeological site condition along the Colorado River in Grand Canyon National Park, Arizona, in Melis, T.S., Hamill, J.F., Benett, G.E., Coggins, L.G, Jr., Grams, P.E., Kennedy, T.A., Kubly, D.M., and Ralston, B.E., eds., Proceedings of the Colorado River Basin Science and Resource Management Symposium, November 18-20, 2008, Scottsdale, Ariz.: U.S. Geological Survey Scientific Investigations Report 2010-5135, p. 333-342, at http://pubs.usgs.gov/sir/2010/5135/.

Flint, K.E., 1982, Chines on the Isle of Wight-Channel adjustment and basin morphology in relation to cliff retreat: The Geographical Journal v. 148, no. 2, p. 225-236.

Geib, P.R., 1990, Prehistoric and historic archeological remains of Glen Canyon downriver from the Glen Canyon Dam: Northern Arizona University, Archeological report no. 1006, 178 p., submitted to the National Park Service, Intermountain Regional Office, Denver, Colorado, report on file at National Park Service.

Geib, P.R., 1996, Glen Canyon Revisited: Salt Lake City, University of Utah Press, University of Utah Anthropological Papers No. 119, 223 p.

Grams, P.E., Schmidt, J.C., and Topping, D.J., 2007, The rate and pattern of bed incision and bank adjustment on the Colorado River in Glen Canyon downstream from Glen Canyon Dam, 1956-2000: Geological Society of America Bulletin, v. 119, no. 5/6, p. 556-575.

Greenlee, D.D., 1987, Raster and vector processing for scanned linework: Photogrammetric Engineering and Remote Sensing, v. 53, no. 10, p. 1383-1387, accessed June 2, 2014 at http://www.asprs.org/Photogrammetric-Engineering-and-Remote-Sensing/PE-RS-Journals.html.

Hazel, J.E., Jr., Grams, P.E., Schmidt, J.C., and Kaplinski, M., 2010, Sandbar response in Marble and Grand Canyons, Arizona, following the 2008 high-flow experiment on the Colorado River: U.S. Geological Survey Scientific Investigations Report 2010-5015, 52 p., at http://pubs.usgs.gov/ sir/2010/5015/. 
Hazel, J.E., Jr., Kaplinski, M, Parnell, R.A., Kohl, K., and Schmidt, J.C., 2008, Monitoring fine-grained sediment in the Colorado River ecosystem, Arizona-Control network and conventional survey techniques: U.S. Geological Survey Open-File Report 2008-1276, 15 p., at http://pubs. usgs.gov/of/2008/1276/.

Hereford, R., Fairley, H.C., Thompson, K.S., and Balsom, J.R., 1993, Surficial geology, geomorphology and erosion of archeological sites along the Colorado River, Eastern Grand Canyon, Grand Canyon National Park, Arizona: U.S. Geological Survey Open-File Report 93-517, 46 p.

Hereford, R., Thompson, K.S., Burke, K.J., and Fairley, H.C., 1995, Late Holocene debris fans and alluvial chronology of the Colorado River, eastern Grand Canyon, Arizona: U.S. Geological Survey Open-File Report 95-57, 28 p. and maps, at http://pubs.usgs.gov/of/1995/0057/report.pdf.

Hereford, R., Thompson, K.S., Burke, K.J., and Fairley, H.C., 1996, Tributary debris fans and late Holocene alluvial chronology of the Colorado River, eastern Grand Canyon, Arizona: Geological Society of America Bulletin, v. 108, no. 1, p. 3-19.

Horton, R.E., 1945, Erosional development of streams and their drainage basins-Hydrophysical approach to quantitative morphology: Geological Society of America Bulletin, v. 56 , p. $275-370$.

Jennings, J.D., 1998, Glen Canyon—An archeological summary: Salt Lake City, University of Utah Press, 131 p.

Jenson, S.K., and Domingue, J.O., 1988, Extracting topographic structure from digital elevation data for geographic information system analysis: Photogrammetric Engineering and Remote Sensing, v. 54, no. 11, p. 1593-1600, accessed January 18, 2014, at http:// $\mathrm{m} 1$.archiveorange.com/m/att/H2CPn/ArchiveOrange_ BqIHJa44tNzoGVG7sjCx1900baoa.pdf.

Kirkby, M.J., and Bracken, L.J., 2009, Gully processes and gully dynamics: Earth Surface Processes and Landforms, v. 34, no. 14, p. 1841-1851, doi: 10.1002/esp.1866.

Leap, L.M., and Neal, L.A., 1992, Testing and charcoal sampling at $C: 2: 32$, river mile $-9.8 \mathrm{LB}$ and $\mathrm{C}: 2: 100$, river mile -0.4 LB, Glen Canyon National Recreation Area: Page, Ariz., National Park Service, Glen Canyon National Recreation Area, Cultural Program Files, report on file at National Park Service.

Leckie, D.G., Gougeon, F.A., Walsworth, N., and Paradine, D., 2003, Stand delineation and composition estimation using semi-automated individual tree crown analysis: Remote Sensing of Environment, v. 85, p. 355-369.
Lucchitta, I., 1991, Quaternary geology, geomorphology, and erosional processes, eastern Grand Canyon, Arizona: U.S. Geological Survey administrative report submitted to Bureau of Reclamation, Upper Colorado Region, Salt Lake City, Utah, report on file at Bureau of Reclamation.

McKee, E.D., 1938, Original structures in Colorado River flood deposits of Grand Canyon: Journal of Sedimentary Petrology, v. 8, no. 3, p. 77-83.

Melis, T.S., ed., 2011, Effects of three high-flow experiments on the Colorado River ecosystem downstream from Glen Canyon Dam, Arizona: U.S. Geological Survey Circular 1366, 147 p., at http://pubs.usgs.gov/circ/1366/.

Neff, L.C., and Wilson, M.A., 2002, Archeological investigations at Ferry Swale Bench - Glen Canyon National Recreation Area, Arizona, Part 1: Archeological testing at site AZ C:02:75(GC): Tucson, Ariz., National Park Service Intermountain Region Western Archeological and Conservation Center Publications in Anthropology, v. 81, 82 p.

Pederson, J.L., O’Brien, G., Neff, T., and Spurr, K., 2011, Grand Canyon geoarchaeology project - report on data recovery at nine cultural sites in Grand Canyon and Lower Glen Canyon, 2008-2010: Utah State University report submitted to Bureau of Reclamation, Upper Colorado Region, Salt Lake City, Utah, report on file at Bureau of Reclamation.

Pederson, J.L., Petersen, P.A., and Dierker, J.L., 2006, Gullying and erosion control at archeological sites in Grand Canyon, Arizona: Earth Surface Processes and Landforms, v. 31 , no. 4 , p. $507-525$.

Pederson, J.L., Petersen, P.A., Macfarlane, W.W., Gonzales, M.F., and Kohl, K., 2003, Mitigation, monitoring, and geomorphology related to gully erosion of cultural sites in Grand Canyon: Flagstaff, Ariz., cooperative agreement no. 01 WRAG0074 between Utah State University and U.S. Geological Survey, Grand Canyon Monitoring and Research Center, 250 p., accessed August 1, 2008, at http://www. gcmrc.gov/library/reports/cultural/Archaeology/Pederson2003.pdf.

Perron, J.T., Dietrich, W.E., and Kirchner, J.W., 2008, Controls on the spacing of first-order valleys: Journal of Geophysical Research, v. 113, no. F4, doi:10.1029/2007JF000977.

Sankey, J.B., Draut, A.E., 2014, Gully annealing by aeolian sediment-field and remote-sensing investigation of aeolian-hillslope-fluvial interactions, Colorado River corridor, Arizona, USA: Geomorphology, v. 220, p. 68-80, doi:10.1016/j.geomorph.2014.05.028. 
Schmidt, J.C., Topping, D.J., Grams, P.E., and Hazel, J.E., 2004, System-wide changes in the distribution of fine sediment in the Colorado River corridor between Glen Canyon Dam and Bright Angel Creek, Arizona: Flagstaff, Ariz., final report to the USGS Grand Canyon Monitoring and Research Center, 117 p., at http://www.gcmrc.gov/library/reports/ physical/Fine_Sed/Schmidt2004.pdf.

Schmidt, J.C., and Grams, P.E., 2011a, The high flows-physical science results, in Melis, T.S., ed., Effects of three high-flow experiments on the Colorado River ecosystem downstream from Glen Canyon Dam, Arizona: U.S. Geological Survey Circular 1366, p. 53-91, at http://pubs.usgs.gov/circ/1366/.

Schmidt, J.C., and Grams, P.E., 2011b, Understanding physical processes of the Colorado River, in Melis, T.S., ed., Effects of three high-flow experiments on the Colorado River ecosystem downstream from Glen Canyon Dam, Arizona: U.S. Geological Survey Circular 1366, p. 17-51, at http://pubs. usgs.gov/circ/1366/.

Schumm, S.A., 1977, Coastal plain, chap. 8 of The fluvial system: Caldwell, N.J., Blackburn Press, 338 p.

Schumm, S.A., Harvey, M.D., and Watson, C.C., 1984, Incised channels-Morphology, dynamics, and control: Littleton, Colo., Water Resources Publications, 220 p.

Selby, M.J., 1985, Hillslope hydrology, chap. 8 of Earth's changing surface: New York, Oxford University Press, 607 p.

Spurr, K. and Collette, J.H., 2007, Condition assessment and significance evaluation for cultural resources between Glen Canyon Dam and Paria Riffle, Glen Canyon National Recreation Area, Arizona: Navajo Nation Archaeology Department Report No. 05-123, submitted to Bureau of Reclamation, Upper Colorado Region, Salt Lake City, Utah, report on file at Bureau of Reclamation.

Tarboton, D.G., Bras, R.L., and Rodriguez-Iturbe, I., 1991, On the extraction of channel networks from digital elevation data: Hydrological Processes, v. 5, no. 1, p. 81-100, at http:// dx.doi.org/10.1002/hyp.3360050107.

Thompson, K.S., and Potochnik, A.R., eds., 2000, Development of a geomorphic model to predict erosion of pre-dam Colorado River terraces containing archeological resources: SWCA Cultural Resources Report 99-257, 227 p., submitted to Grand Canyon Monitoring and Research Center, Flagstaff, Arizona, accessed June 2, 2014 at http://www.riversimulator. org/Resources/GCMRC/Cultural/Thompson2000b.pdf.

Topping, D.J., Schmidt, J.C., and Vierra, L.E., Jr., 2003, Computation and analysis of the instantaneous-discharge record for the Colorado River at Lees Ferry, Arizona-May 8, 1921, through September 30, 2000: U.S. Geological Survey Professional Paper 1677, 125 p., http://pubs.usgs.gov/pp/ pp1677/.
Turner, R.M., and Karpiscak, M.M., 1980, Recent vegetation changes along the Colorado River between Glen Canyon Dam and Lake Mead, Arizona: U.S. Geological Survey Professional Paper 1132, 131 p., at http://pubs.usgs.gov/ pp/1132/report.pdf.

U.S. Department of the Interior, 1995, Operation of Glen Canyon Dam final impact statement: Salt Lake City, Utah, Bureau of Reclamation, Upper Colorado River Region, 337 p. and appendices, at http://www.usbr.gov/uc/envdocs/eis/ gc/gcdOpsFEIS.html.

Waring, G.L., 1996, Current and historical riparian vegetation trends in Grand Canyon, using multitemporal remote sensing analyses of GIS sites: Cooperative agreement no. CA 8000-8-0002 between Northern Arizona University and the National Park Service, 50 p., accessed January 13, 2014, at http://www.gcmrc.gov/library/reports/GCES/Biological/Terrestrial/Waring1996.pdf.

Wilson, M.A., and Neff, L.C., 2002, Archeological investigations at Ferry Swale Bench: Glen Canyon National Recreation Area, Arizona, part 2-Archeological testing at site AZ C:02:77 (GC): Tucson, Ariz., National Park Service Intermountain Region Western Archeological and Conservation Center Publications in Anthropology, v. 81, 107 p.
Menlo Park Publishing Service Center, California Manuscript approved for publication July 2, 2014 Edited by Larry Slack and Kate Burgy Design and layout by Vivian Nguyen 
